\title{
Ellipsis in Dutch possessive noun phrases: a micro-comparative approach
}

\author{
Norbert Corver $\cdot$ Marjo van Koppen
}

Received: 14 November 2007 / Accepted: 1 February 2009 / Published online: 7 March 2010

C) The Author(s) 2010. This article is published with open access at Springerlink.com

\begin{abstract}
We discuss ellipsis of the possessee in both pronominal possessor constructions (Dutch: zijn boek 'his book') and possessor doubling constructions (Dutch: John z'n boek, John his book 'John's book') from a micro-comparative perspective. More specifically we show, on the basis of an in-depth study of the nominal system of 57 Dutch dialects, that there are two types of possessee ellipsis. In the first type there is a pro which needs to be licensed by gender agreement. In the second type there is an overt pro-form, similar to English one, and hence no ellipsis. Dialects that have the first type of possessee ellipsis can be further divided into two subtypes. The first has gender agreement on the possessive pronoun, the second one does not. Interestingly, possessee ellipsis can take place in the possessor doubling construction only in the former subtype of dialect. We implement this striking generalization by arguing that in the latter type of dialect pro has to move to Spec,DP in order to be licensed. The doubling possessor also has to be merged in Spec,DP. As a consequence, pro and a doubling possessor cannot co-occur and hence possessee ellipsis and possessor doubling are incompatible. In the former type of dialect, i.e., those dialects that do express gender on the possessive pronoun, pro can be licensed by the gender agreement on the possessive pronoun in a position lower than Spec,DP. Hence, in these dialects Spec,DP is available for a doubling possessor and, consequently, possessee ellipsis and possessor doubling can co-occur.
\end{abstract}

Keywords Gender · NP-ellipsis · One-insertion · Possessive constructions ·

Possessor doubling

\section{Introduction}

In the past decades, ample attention has been paid in the literature to DP-internal possessive constructions from a generative perspective (cf. among others Szabolcsi

N. Corver $\cdot$ M. van Koppen $(\triangle)$

University of Utrecht, UiL-OTS, Trans 4, 3512 JK Utrecht, Netherlands

e-mail: j.m.vankoppen@uu.nl 
1994; Den Dikken 2006). The main goal of these papers is to identify the DPinternal structure of possessive constructions on the basis of either the data from a single language or macro-comparative data. The paper at hand contributes to the debate on the DP-internal structure of possessive constructions in two ways. First of all, it discusses new empirical data, namely microcomparative data from Dutch dialects. Secondly, it investigates the fairly neglected issue concerning ellipsis in possessive constructions (see, though, Schoorlemmer 1998; Corver and Van Oostendorp 2005). As such, this paper will not only enhance our understanding of DP-internal possessive constructions, but it will also provide insight into which factors play a role in this instance of noun phrase internal ellipsis.

Possessive constructions in variants of Dutch can contain just a possessive pronoun, as in example (1a) (henceforth: pronominal possessor construction), or a possessive pronoun and a 'doubling' XP-possessor (henceforth: possessor doubling construction), as in example (1b) (cf. Corver 1990; Van de Craats et al. 2000). ${ }^{1}$

a. z'n auto

his car

'his car' pronominal possessor construction

\footnotetext{
used, as shown in (ii).

(i) a. zijn auto 'his car' haar auto 'her car'

b. z'n auto 'his car' d'r auto 'her car'

(ii) a. John z'n auto John his car 'John's car'

b. Marie d'r auto Marie her car 'Mary's car'
}

${ }^{1}$ Dutch distinguishes both phonologically strong possessive pronominal forms (cf. (ia)) and phonologically weak ones (cf. (ib)). In non-elliptical possessor doubling constructions, the weak pronominal form is typically

Besides the pronominal possessor construction and the possessor doubling construction, Dutch also expresses possession within the DP by means of an analytical construction featuring van 'of' and a pattern in which the bound morpheme $-s$ appears attached to a prenominal possessor.

(iii) a. de auto van John

$$
\text { the car of John 'John's car' }
$$

b. John-s auto

John's car 'John's car'

Since the patterns in (iii) are not relevant for the paper at hand, we will not further discuss them here. 
b. Teun z'n auto possessor doubling construction

Teun his car

'Teun's car'

(standard Dutch)

Interestingly, the variants of Dutch that we have investigated all display a system similar to the one illustrated in (1). However, although these attributive instances of the possessive construction are not subject to micro-variation, there is a lot of variation when ellipsis in these two types of possessive constructions is taken into account. With ellipsis in possessive constructions we refer to the pre-theoretical meaning of the word 'ellipsis', namely the possibility to leave the possessee unpronounced. An example from English is provided in $(2 a-b)$. In (2a) the possessee is elided following the possessive pronoun mine and in (2b) the possessee is elided in a possessive construction with a proper name as possessor.

(2) a. I like your bike and you like mine

b. I like John's bike and you like Mike's

(English)

We show that Dutch dialects can be divided into two groups displaying two different strategies to deal with ellipsis of the possessee in possessive constructions. The first one is to express the gender features of the absent possessee on the remnant of ellipsis. We show that in dialects using this first strategy there is a pro occupying the possessee position. This pro gets licensed by gender agreement on the remnant of ellipsis. The second strategy, as utilized by the second group of Dutch dialects, is to add an invariant affix to the possessive pronoun. We argue that in this case there is actually no ellipsis, i.e., the possessee is not unpronounced. Rather, the possessee is expressed by a pronominal element which surfaces as an invariant affix on the possessive pronoun. This latter strategy is reminiscent of one-insertion in English. We will come back to the relation between the appearance of the invariant affix in Dutch dialects and one-insertion in English in Section 5 below.

The data presented in this paper are collected as part of the DiDDD-project ${ }^{2}$ (Diversity in Dutch $\underline{\text { PP }}$ Design), which is executed at the University of Utrecht (see

\footnotetext{
$\overline{{ }^{2} \text { For more information visit the following website: http://www.let.uu.nl/ } ~ H u i b . K r a n e n d o n k / p e r s o n a l / ~}$
} 
Corver et al. 2007). For this project the nominal system of 53 dialects, evenly distributed over the Netherlands and Flanders (the Dutch speaking part of Belgium), has been investigated in depth. The figure in (3) provides a map which shows all the dialects included in this research project. To our knowledge, the data discussed in this paper provide an exhaustive overview of the variation attested in ellipsis within possessive noun phrases in the Dutch language area. In this paper we use only a few dialects to exemplify the patterns we have attested. Each dialect represents a much larger set of dialects. These dialects have a distinct marking in the figure in (3).

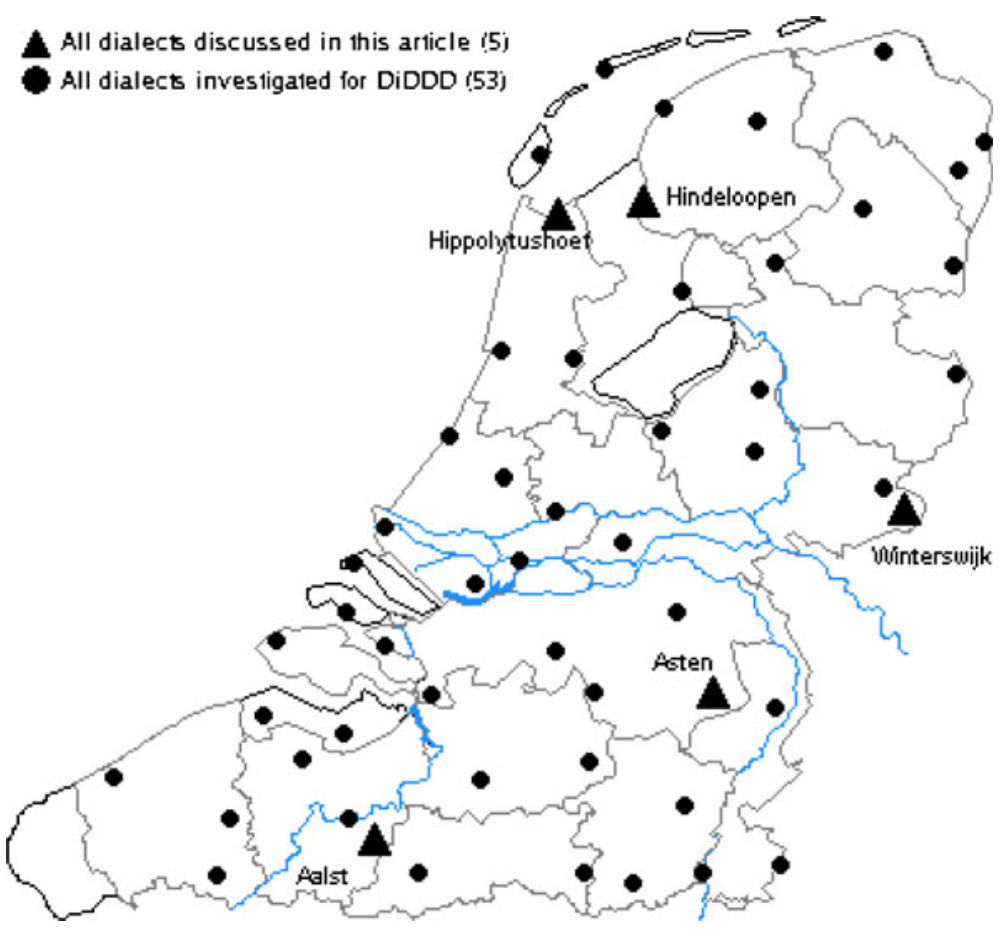

This paper is organised as follows. In Section 2 we describe the two licensing strategies briefly introduced above for ellipsis in the pronominal possessor constructions, i.e., the possessive construction illustrated in example (1a), in variants of Dutch in detail. Section 3 presents an analysis of these two strategies. In Section 4, in which we discuss ellipsis in the possessor doubling construction, we provide additional evidence for this analysis. In Section 5 we conclude the paper and discuss the data and analyses provided in this paper from a meso-comparative angle.

\section{Two licensing strategies for ellipsis in pronominal possessive constructions}

As was already mentioned briefly in the introduction to this paper, variants of Dutch differ substantially as to how they deal with ellipsis in the pronominal possessor 
construction. In this subsection we will look more closely into this type of microvariation. Consider the examples in (4). ${ }^{3}$
a. mijn vader
- de mijne
b. mennen traktor
the mine
my tractor
c. mienen hood
my hat
d. mien aaite
- de mainn
the mine
- (de) mien-en
(the) mine - affix
- (*de) mien-en
my grandfather
(the) mine -affix

(standard Dutch)

(Wambeek Dutch)

(Winterswijk Dutch, Deunk 1977)

(Hindeloopen Frisian)

There is one prominent characteristic of ellipsis in the pronominal possessor construction, namely the fact that in several dialects a definite article appears when the possessee is elided. There is no dialect of Dutch in which this definite article can appear when the possessee is not elided. This means that the appearance of the definite article is linked to the ellipsis of the possessee in this construction. We discuss the properties of the definite article in this construction in detail in Section 3.1.2.

As example (4) shows, some dialects (like standard Dutch (4a) and Wambeek Dutch (4b)) obligatorily have a definite determiner accompanying the possessive pronoun when the possessee is elided. Other dialects, like Winterswijk Dutch, optionally allow the presence of a definite article. A third group of dialects does not allow the presence of a definite article in ellipsis contexts at all, see example (4d) from Hindeloopen Frisian.

Another difference between the dialects in this example becomes clear if we compare Winterswijk Dutch, example (4c), and Hindeloopen Frisian, example (4d). These dialects differ with respect to each other concerning the status of the en-affix. In Winterswijk Dutch, the en-affix is present in the construction independent of whether there is ellipsis or not. In Hindeloopen Frisian, however, this affix only appears if the possessee is elided. We argue that the difference between these dialects is that the en-affix in Winterswijk Dutch is a gender agreement ending dependent on the gender features of the possessee. However, the en-affix in Hindeloopen Frisian is invariant for gender. We show that this latter affix is actually an indefinite pronoun, comparable to English one in one-insertion contexts, replacing the possessee.

We argue on the basis of the differences between these dialects that there are two different types of dialects: (i) dialects in which the possessee undergoes ellipsis and the remnant of ellipsis optionally or obligatorily contains a definite article (strategy 1), and (ii) dialects in which the possessive pronoun which is the remnant of possessee ellipsis carries an affix which is invariant for the gender of the elided noun (strategy 2). The first three dialects illustrated in (4), namely standard Dutch, Wambeek Dutch, and Winterswijk Dutch, are examples of dialects which use the first strategy. Hindeloopen Frisian, exemplified in (4d), is a representative of the second strategy.

\footnotetext{
${ }^{3}$ Note that the $e$-ending appearing on the possessive pronoun in the standard Dutch example (4a) does not express gender agreement. The $e$-ending appears in all person/number combinations.
} 


\subsection{Strategy 1: a definite article on the remnant of ellipsis}

We start by taking a closer look at the first type of dialect, i.e., the dialects in which the remnant of ellipsis has to realize the gender features of the elided possessee noun. The dialects using strategy 1 differ in whether or not a definite article is obligatorily present on the remnant of ellipsis. Some dialects using strategy 1, like standard Dutch, must have a definite article on the remnant of ellipsis, see example (5a). In other variants of Dutch, like Winterswijk Dutch, the definite article is optional, see example (5b).
a. (*de) mijn auto
the my car-
'my car'
- *(de) mijne
the-
'mine'
b. (*d'n) mien-en hood - (d'n) mienen
(the) my- MASC $_{\text {Mat }}$ the- MASC $_{\text {MASC }}$ mine- ${ }_{\text {MASC }}$ 'my hat' 'mine'
(Winterswijk Dutch: Deunk 1977)
(standard Dutch)

We show that the generalization in (6) holds for the dialects using strategy 1.

(6) Generalization

The definite article is optional on the remnant of possessee ellipsis if every possessive pronoun in the possessive pronoun paradigm represents the full range of gender specifications available in the dialect.

The definite article is obligatorily present on the remnant of possessee ellipsis if the gender information on one or more possessive pronoun(s) in the possessive pronoun paradigm represents only a subset of the gender specifications available in the dialect.

Now reconsider the examples in (5). Standard Dutch distinguishes between two genders: common gender and neuter gender. Auto 'car' is a noun with common gender. Possessive pronouns do not express gender in standard Dutch with the exception of the first person plural pronoun ons/onze ' $\mathrm{us}_{\text {NEUTER }} / \mathrm{us}_{\text {COMMON }}$ '. This means that standard Dutch is a variant of Dutch in which one or more possessive pronouns in the paradigm only represent a subset of the gender specifications of the elided possessee, as we will show below. The definite article in standard Dutch does have a different form depending on whether it appears with nouns in the common gender and nouns in the neuter gender. When the possessee is elided in this variant of Dutch, see example (5a), a definite article has to appear. Now consider the example in (5b). All possessive pronouns in Winterswijk Dutch, as we will show below, mark the full range of gender specifications, i.e., they all distinguish between neuter, masculine, and feminine. The definite article is optional in this variant of Dutch.

Now that the general idea of how this generalization works is clear, let us see how it works in detail. We discuss four dialects in detail representing the full range of variation we find within this strategy. Again it needs to be said that each of these dialects represents a much larger set of dialects. The first three dialects we discuss all have a three-way gender system: they distinguish between masculine, feminine, and neuter gender. The first one, Asten Dutch, does not make the 
relevant three-way gender distinction on the possessive pronoun: it only marks masculine gender. We show that in this dialect a definite article has to be added when the possessee is elided. The second one, Winterswijk Dutch, makes the relevant three-way gender distinction on the possessive pronoun. In this dialect the definite article in ellipsis contexts is optional. Thirdly, in Aalst Dutch the possessive pronoun only makes the required three-way gender distinction in a subset of the possessive pronouns in the paradigm. The definite article has to appear in this dialect when the possessee is elided. Finally we discuss standard Dutch. This variant only makes a two-way gender distinction between neuter and common gender, as discussed above. The possessive pronoun is invariant for gender in this variant of Dutch. The definite article always has to be added when the possessee is elided in this dialect.

\subsubsection{Asten Dutch}

We start with Asten Dutch. This dialect morphologically distinguishes all three genders in the singular, as is illustrated in (7). The plural has the same form as the feminine singular. ${ }^{4}$

(7) a. masculine singular: nen opa de oom 'a grandfather, the uncle'
b. feminine singular: een oma de dame 'a grandmother, the lady'
c. neuter singular: een keind 't kenijn 'a child, the rabbit'
d. plural:

(Asten Dutch)

The masculine form differs from feminine and neuter in the indefinite article paradigm. Neuter has a different form than masculine and feminine in the definite article paradigm. We take this to mean that in this dialect nouns are specified for masculine, feminine, or neuter gender. ${ }^{5}$

In this dialect the possessive pronoun also agrees in gender with the possessee. This is illustrated in example (8). The possessive pronoun has a distinct marking for the masculine gender.
a. masculine singular: minnen opa
b. feminine singular: min tante
c. neuter singular: min keind
'my grandfather'
d. plural:
'my aunt'
'my child'
'my children'

(Asten Dutch)

\footnotetext{
${ }^{4}$ Since plural nouns in Dutch usually cannot be accompanied by indefinite articles, we use the form geen 'no', which has the same paradigm as the indefinite article, in this and the following examples.

${ }^{5}$ As the plural forms of the definite and indefinite article correspond to the feminine singular forms, one could also argue that the dialect only distinguishes masculine and neuter gender. If the noun is neither masculine singular nor neuter singular, the default "feminine" form is used. As will become clear from the discussion of several other dialects, it is often the case that feminine singular and plural forms are similar. At present we do not have an explanation for this empirical fact.
} 
If the possessee is elided in this dialect, the definite article obligatorily appears as a part of the remnant of ellipsis, as is illustrated in (9).

$\begin{array}{lll}\text { (9) a. masculine singular: de minnen } & \text { 'mine' } \\ \text { b. feminine singular: de min } & \text { 'mine' } \\ \text { c. neuter singular: } & \text { t min } & \text { 'mine' } \\ \text { d. plural: } & \text { de } \min & \text { 'mine' }\end{array}$

(Asten Dutch)

As pointed out above, the dialect has a three-way gender system. The possessive pronoun paradigm only distinguishes between masculine gender on the one hand and the other two genders, i.e., neuter and feminine, on the other. In this dialect a definite article has to be added when the possessee is elided.

\subsubsection{Winterswijk Dutch}

Now reconsider Winterswijk Dutch, which was already briefly introduced in example (5). This dialect, just like Asten Dutch, has a three-way gender system: nouns are also either masculine, feminine, or neuter. In contrast to Asten Dutch, this three-way distinction is fully represented in the definite article paradigm, see example (10).

(10) a. masculine singular: den hood
b. feminine singular: de muts the hat'
$\begin{array}{ll}\text { c. neuter singular: the bonnet' } \\ \text { d. plural: }\end{array}$ 'the house'

(Winterswijk Dutch: Deunk 1977)

The possessive pronoun in this dialect, just like in Asten Dutch, agrees in gender with the possessed noun, as was already illustrated in (5). In contrast to Asten Dutch, the possessive pronoun paradigm in this dialect also distinguishes between all three genders, see the example in (11).
a. masculine singular: mien-en hood
'my hat'
b. feminine singular: mien-e muts
'my bonnet'
c. neuter singular:
mien hoes
'my house'
d. plural:
mien-e mutse
'my bonnets'

(Winterswijk Dutch: Deunk 1977)

All possessive pronouns in this dialect make this three-way gender distinction. Now consider the example in (12) which illustrates the possessive pronoun paradigm after the possessee has undergone ellipsis.
a. masculine singular: (d'n) mienen
'mine'
b. feminine singular:
(de) miene
'mine'
c. neuter singular:
t miene
'mine'
d. plural:
(de) miene
'mine'

(Winterswijk Dutch: Deunk 1977) 
On the basis of the paradigm in (11) and the generalization in (6), we expect the definite article to be optional in this dialect, since all possessive pronouns make all the relevant gender distinctions. As the paradigm in (12) shows this is indeed the case for all person/gender combinations except for the combination neuter singular. The remnant possessive pronoun in the neuter singular has an additional $e$-ending which is not present in the attributive paradigm. ${ }^{6}$ One option would be to suggest that the $e$-ending is present to make the form of the neuter singular possessive pronoun phonologically heavier. This is a pattern we see throughout the variants of Dutch: the remnant possessive pronouns are phonologically heavier than the attributively used ones. For instance, this can also be argued to be the case in standard Dutch: in this variant the substantive form of the possessive pronoun is also followed by an $e$-ending which is absent in the attributive form and which makes the possessive pronoun phonologically heavier (or a strong pronoun, according to Schoorlemmer 1998). Although we do not have a full-fledged analysis for this pattern, we would like to suggest that this might be an instance of the more general pattern that attributes stress or focus to the remnant of ellipsis.

However, in Winterswijk Dutch, this $e$-ending does not only make the possessive pronoun phonologically heavier, it also obscures the distinction between neuter gender and feminine gender. Below, in Section 3, we argue that this is the reason the definite article is obligatorily present in this person/gender combination in this dialect.

\subsubsection{Aalst Dutch}

A dialect which is again subtly different from Winterswijk Dutch and Asten Dutch is Aalst Dutch. In this dialect there is, just like in the other two dialects, a three-way gender distinction. Consider the examples in (13) and (14). ${ }^{7,8}$
a. masculine singular: de(n) hond
ne(n) hond
'the dog/a dog'
b. feminine singular: de koe
en koe
c. neuter singular: t kiendje e kiendj
'the cow/a cow'
'the child/a child'

(Aalst Dutch)

(14) a. masculine singular: mèn-n auto

b. feminine singular: mèn koe

c. neuter singular: mè kiendj

d. plural:

mèn kingern

'my car'
'my cow'
'my child'
'my children'

(Aalst Dutch)

These examples show that the definite article, the indefinite article and the possessive pronoun all make the three-way distinction between masculine, feminine and neuter in this dialect. On the basis of this we would expect that the definite

\footnotetext{
$\overline{{ }^{6} \text { A schwa-ending or schwa-affix }}$ is orthographically represented by $e$-ending or $e$-affix.

${ }^{7}$ The final $n$ in the masculine singular only appears when it is followed by a vowel or certain consonants.

${ }^{8}$ The possessive pronoun and the indefinite article in Aalst Dutch in the neuter singular have the form men and $e n$ in a restricted set of phonological contexts.
} 
article is optionally present when the possessee is elided. This is not the case, however, as illustrated in (15).
a. masculine singular: de mèn-n
'mine'
b. feminine singular: de mèn
'mine'
c. neuter singular: $t$ mèn
'mine'
d. plural:
de mèn
'mine'

(Aalst Dutch)

These examples show two things. First of all, the definite article is obligatorily present in this dialect, and secondly, the distinction between neuter and the other genders is obviated by the addition of a $n$-ending in the neuter singular. Again, we assume that the latter difference between the attributive and the substantive paradigm is a way to make the form of the remnant pronoun in the neuter singular phonologically heavier in order to add stress or focus to the remnant of ellipsis. However, the question arises why in this dialect the definite article is not optional in the other gender/number combinations, as in Winterswijk Dutch, where the same situation occurs. In this type of dialect, in contrast to dialects like Winterswijk Dutch, the distinction between the three genders is only present on a subset of the pronouns in the possessive pronoun paradigm, namely only with the possessive pronouns men 'my' and zen 'his'. The other possessive pronouns only have a distinct ending for masculine gender. As a consequence, the definite article is obligatorily present. Consider for instance the paradigm of the possessive pronoun eur 'her' and oa 'your' below.
a. masculine singular: eur'n auto oa-n auto 'her car, your car'
b. feminine singular: eur koe oa koe 'her cow, your cow'
c. neuter singular: eur kiendj oa kiendj 'her child, your child'
d. plural: eur kingern oa kingern 'her childeren, your childeren'

(Aalst Dutch)

\subsubsection{Standard Dutch}

Finally let us take a closer look at standard Dutch. As already discussed above this variant of Dutch, in contrast to the three dialects discussed above, has a two-way gender system. It morphologically distinguishes between neuter gender and common gender/non-neuter gender. ${ }^{9}$ The gender distinctions are only visible on the definite article; the indefinite article is invariant for gender. This is illustrated in example (17).
a. non-neuter singular: de man,
een man
'the man, a man'
b. neuter singular:
het kindje, een kindje
'the child, a child'
c. plural:
de kinderen, geen kinderen 'the children, no children'

(standard Dutch)

\footnotetext{
${ }^{9}$ It is clear that there are nouns in Dutch which can unambiguously be semantically identified as feminine or masculine, as in any other language. However, there is no morpho-syntactic reflex of this semantic gender specification within the noun phrase. We take this to mean that the gender distinction between masculine and feminine is not present in the formal feature make up of lexical items in Dutch.
} 
In contrast to the dialects discussed above, possessive pronouns in standard Dutch do not agree in gender with the possessed noun, see example (18).
a. non-neuter singular: mijn man
'my man'
b. neuter singular:
mijn kindje
'my child'
c. plural:
mijn kinderen
'my children'

(standard Dutch)

Standard Dutch also differs from the dialects discussed above in that the possessive pronoun has another form in ellipsis contexts than in attributive contexts. The form used in ellipsis contexts has an extra schwa (orthographically represented as $-e$ ) added to it in all genders. So, the attributive form mijn 'my' becomes mijne 'mine' in ellipsis contexts. This form of the possessive pronoun, in the literature referred to as the strong form of the possessive pronoun (see, e.g., Schoorlemmer 1998), is also invariant for gender (cf. also footnote 3 and the discussion on the insertion of an $e$-affix in Section 2.1.2 above). Since the possessive pronoun does not show any gender distinctions in standard Dutch, the article has to be present in order to express the gender features of the elided possessee. The relevant examples are provided in (19).
a. non-neuter singular: de mijne
'mine'
b. neuter singular:
het mijne
'mine'
c. plural:
de mijne
'mine'

(standard Dutch)

\subsubsection{Summary}

To summarise, in this section we have investigated the conditions that lead to the optional or obligatory addition of a definite article when the possessee is elided. We have illustrated that this definite article is obligatory in dialects like Asten Dutch, Aalst Dutch, and standard Dutch. In these dialects one or more of the possessive pronouns in the paradigm do not have a distinctive form for (all of) the gender specifications available in the dialect. In dialects like Winterswijk Dutch all possessive pronouns have a distinctive form for all the gender specifications available in the dialect. In this latter type of dialect, the definite article is optional when the possessee is elided.

\subsection{Strategy 2: an affix on the remnant of ellipsis}

In the second type of dialect, the remnant of ellipsis in the pronominal possessor construction carries an affix which is invariant for gender. This affix cannot be present when the possessive pronoun is used attributively and ellipsis of the possessee has not taken place. Consider in this respect the Frisian dialect of Hindeloopen.

This dialect is in many respects similar to standard Dutch. Just like standard Dutch it has a two-way gender system: the DP-internal morphology distinguishes between neuter gender and common/non-neuter gender. Also similarly to standard 
Dutch, this distinction is made only on the definite article in this dialect; the indefinite article is invariant. This is illustrated in example (20).
a. masculine singular: de umke
een aaite
'the uncle, a grandpa'
b. feminine singular: de dame
een aame
c. neuter singular: 't knientjen
een bon
'the lady, a grandma'
d. plural:
de hiengsten geen boeken
'the rabbit, a child'
'the horses, no books'

(Hindeloopen Frisian)

The example in (21) shows that in Hindeloopen Frisian, again just like in standard Dutch, the possessive pronoun does not agree in gender with the possessed noun.
a. masculine singular: mien aaite
'my grandfather'
b. feminine singular: mien tante
'my aunt'
c. neuter singular:
mien bon
'my child'
d. plural:
mien bon
'my children'

(Hindeloopen Frisian)

Hindeloopen Frisian differs from standard Dutch when the remnant possessive pronouns are taken into account: in Hindeloopen Frisian there is no gender marking on the remnant of ellipsis as there is in standard Dutch (see example (19)); rather, an invariant en-affix or $s$-affix appears on the remnant of possessee ellipsis in this dialect. The en-affix appears with the singular possessive pronouns and the $s$-affix with the plural possessive pronouns. This is illustrated in (22).
a. masculine singular: mien-en
'mine'
uze-s 'ours'
b. feminine singular: mien-en
'mine'
uze-s 'ours'
c. neuter singular:
mien-en
'mine'
uze-s 'ours'
d. plural:
mien-en 'mine'
uze-s 'ours'

(Hindeloopen Frisian)

The question arises what the status of these invariant endings is. Interestingly, the en-affix appears not only in possessive constructions with an elided possessee, but also appears in several other elliptical constructions, see example (23). Apparently the addition of this affix is more generally linked to NP-ellipsis in this dialect.
a. $\mathrm{t}$ wit knientjen en een zwart-en the white rabbit and a black-en 'the white rabbit and a black one'
b. dizze opa en dizz-en this grandfather and this-en 'this grandfather and this one'

(Hindeloopen Frisian)

Another dialect that falls within this type is Hippolytushoef Dutch. This dialect, just like Hindeloopen Frisian and standard Dutch, makes a distinction between 
neuter versus non-neuter/common gender in the definite article paradigm; see example (24).
a. masculine singular: de oom
een opa
b. feminine singular: de dame
een opoe
c. neuter singular: 't kenien
een kien
d. plural:
de peerden
geen boeken

\begin{abstract}
'the uncle, a grandpa'
'the lady, a grandma'

'the rabbit, a child'

'de horses, no books'
\end{abstract}

(Hippolytushoef Dutch)

Also similarly to Hindeloopen Frisian and standard Dutch, this dialect does not have gender inflection on the possessive pronoun. This is illustrated in example (25).
a. masculine singular: mien opa
'my grandfather'
b. feminine singular: mien tante
'my aunt'
c. neuter singular:
mien kien
'my child'
d. plural:
mien kien
'my children'

(Hippolytushoef Dutch)

When ellipsis is applied to the pronominal possessive construction in this dialect, either an invariant $e$-ending or an invariant $s$-ending appears on the remnant of ellipsis, see the examples in (26). The choice for either of these endings depends on the possessive pronoun it attaches to. When the possessive pronoun is mien 'my', jouw 'your', heur 'her', sien 'his', ongs 'our', an e-ending indicates ellipsis of the possessee. When the possessive pronoun is jullie 'your (plural)' or hullie 'their', an $s$-ending appears on the remnant possessive pronouns.
a. masculine singular: mien-e/jullie-s
'mine'/'yours'
b. feminine singular: mien-e/jullie-s
'mine'/'yours'
c. neuter singular:
mien-e/jullie-s
'mine'/'yours'
d. plural:
mien-e/jullie-s
'mine'/'yours'

(Hippolytushoef Dutch)

A similar pattern is found in standard Frisian. This language has a similar pattern to the one discussed above for Hindeloopen Frisian, Hippolytushoef Dutch, and standard Dutch: the definite article has a distinct form for neuter gender and non-neuter gender, and possessive pronouns and indefinite articles are invariant for gender. In Frisian the possessive pronouns which form the remnant of ellipsis of the possessee carry an affix which is invariant for gender. Again there are two invariant affixes: an $s$-ending and an $n$-ending. The former can be used with all person/number/gender combinations of the possessive pronoun; the latter is restricted to the singular possessive pronouns, just as in Hindeloopen Frisian. The Frisian pattern is provided in (27). ${ }^{10}$

$\begin{array}{lllll}\text { (27) } & \text { mines/minen } & \text { dines/dinen } & \text { sines/sinen } & \text { harres uzes jimmes harres } \\ \text { mine } & \text { yours } & \text { his } & \text { hers } & \text { ours yours theirs }\end{array}$

(Frisian)

\footnotetext{
${ }^{10}$ The forms minen, dinen, and sinen can be followed by a so-called paragogic $-t$. We then have: minent, dinent, and sinent. See Corver and Van Oostendorp (2005) for a discussion of the paragogy of the [t] in Dutch dialects.
} 
To summarise, in this type of dialect the remnant of ellipsis does not carry the gender information of the elided noun. Rather, an invariant suffix is attached to it.

\subsection{Summary}

In this section we have given a description of the strategies that are used in the dialects of Dutch to deal with ellipsis of the possessee. We have identified two strategies. The dialects following the first strategy optionally or obligatorily add a definite article to the remnant of ellipsis. We have established that the definite article is optional when all possessive pronouns in the dialect have distinct forms for all the gender specifications that are distinguished in the dialect. In all other dialects the definite article is obligatory when the possessee is elided. The dialects that follow the second strategy add an affix to the possessive pronoun, which is the remnant of possessee ellipsis. This affix is invariant for gender.

\section{Analysis}

In this section we provide an analysis for the variation concerning ellipsis in possessive constructions described in the previous section. Just as in the previous section, we first provide an analysis of dialects utilizing the first strategy: an optional or obligatory definite article on the remnant of possessee ellipsis. In the second subsection we provide an analysis of dialects using the second strategy: an affix invariant for gender appearing on the remnant possessive pronoun.

\subsection{Strategy 1: a definite article on the remnant of ellipsis}

In this subsection we provide an analysis for ellipsis of the possessee in dialects using strategy 1: dialects that optionally or obligatorily add a definite article to the remnant of possessee ellipsis. These dialects overtly and unambiguously realize the gender specification of the possessee on the possessive pronoun which is the remnant of possessee ellipsis. The reason for this is that the position of the possessee is occupied by pro which needs to be licensed and identified by gender agreement.

There are dialects within this subgroup, like Winterswijk Dutch, in which the possessive pronoun makes all the relevant gender distinctions. In those dialects the definite article is optionally present. As regards the dialects in this subgroup in which not all the possessive pronouns make (all) the relevant gender distinctions, like Asten Dutch, Aalst Dutch, and standard Dutch, we argue that the definite article is obligatorily added to make the gender marking on the remnant of ellipsis complete. This means that the presence of the definite article on the remnant of possessee ellipsis is motivated by the gender features of the definite article, rather than by its definiteness feature (reminiscent of the expletive definite article cf. Longobardi 1994, Vergnaud and Zubizarreta 1992). As such it might be analyzed as a gender marker rather than a definiteness marker.

This subsection is organised as follows. We first explore the relation between possessive pronouns and indefinite articles. We show that possessive pronouns and indefinite articles have the same gender specifications. From this we conclude that 
they are both connected to the $\mathrm{Num}^{\circ}$-position in the DP-internal architecture. In the second subsection we provide an analysis for this type of dialect.

\subsubsection{Definite vs. indefinite gender system}

Most dialects of Dutch display two different types of gender system: namely, a system visible on the definite article (henceforth referred to as the definite gender system) and another system on the indefinite article (henceforth referred to as the indefinite gender system). The majority of the dialects have a definite gender system which makes a distinction between neuter and non-neuter. ${ }^{11}$ There are three different types of indefinite gender systems: (i) a distinction between masculine versus nonmasculine, illustrated by Asten Dutch in example (28); (ii) a three-way distinction between masculine, feminine, and neuter, illustrated by Winterswijk Dutch in (29); and (iii) no gender marking at all, illustrated by standard Dutch in (30).

(28) a. masculine singular: de oom,

nen opa 'the uncle, a grandfather'

b. feminine singular: de dame, een oma 'the lady, a grandmother'

c. neuter singular: 't kenijn, een keind 'the rabbit, a child'

d. plural: de pe:rd, geen boeke 'the horses, no books'

(Asten Dutch)

(29) a. masculine singular: den hood,

ne(n) hood 'the hat, a hat'

b. feminine singular: de foute, ne foute 'the mistake, a mistake'

c. neuter singular: het hoes,

n hoes 'the house, a house'

(Winterswijk Dutch: Deunk 1977)

(30) a. non-neuter singular: de man, een man 'the man, a man'

b. neuter singular: het kindje, een kindje 'the child, a child'

c. plural: de kinderen, geen kinderen 'the children, no children'

(standard Dutch)

Interestingly, the possessive pronoun displays the same paradigm as the indefinite article. Consider the examples in (31)-(33), which provide the possessive pronoun paradigms for Asten Dutch, Winterswijk Dutch, and standard Dutch, respectively.
a. masculine singular: min-nen opa
'my grandfather'
b. feminine singular: min tante
'my aunt'
c. neuter singular: min keind
'my child'
d. plural:
min keinder
'my children'

(Asten Dutch)
a. masculine singular: mien-en hood
'my hat'
b. feminine singular: mien-e muts
c. neuter singular: mien hoes
d. plural:
mien-e mutse
'my bonnet'
'my house'
'my bonnets'

(Winterswijk Dutch: Deunk 1977)

\footnotetext{
${ }^{11}$ There are, in our corpus, just two dialects that make a three-way distinction between masculine, feminine, and neuter on the definite article system.
} 
(33)
a. non-neuter singular: mijn opa
'my grandfather'
b. neuter singular:
mijn kind
'my child'
c. plural:
mijn kinderen
'my children'

(standard Dutch)

We take this striking correlation between the possessive pronominal paradigm and the indefinite article paradigm to mean that the possessive pronoun is a combination of two parts: a pronominal part, base generated in Spec,PosP, and an inflectional part, base generated in the same position as the indefinite article, namely $\mathrm{Num}^{\circ}$. The question arises why there is a connection between the gender agreement on the indefinite article and the gender agreement on the possessive pronoun, especially given the fact that possessive noun phrases have a definite interpretation in variants of Dutch. We would like to argue that the indefinite gender agreement appearing in this construction is an indication that possessive pronouns also contain an instance of the so-called spurious indefinite article identified by Bennis et al. (1998) for constructions like those in $(34 a-c)$.
a. die schatten van een kinderen those treasures of $a_{\text {SPURIOUS }}$ children 'those sweet children'
b. wat voor een mensen what for $a_{\text {SPURIOUs }}$ people 'what kind of people'
c. Wat een geld! what $a_{\text {SPURIOUS }}$ money
'What a huge amount of money!'

(standard Dutch)

All these spurious instances of the indefinite article are similar in the sense that they do not act like regular indefinite articles. For instance, spurious indefinite articles appear with nouns that are plural, see (34a-b), or with mass nouns, see (34c). Regular indefinite articles, however, cannot do so (i.e., (*een) kinderen 'children', (*een) geld 'money'). If the indefinite article part of the possessive pronoun is another instance of the spurious indefinite article, then we also expect it to co-occur with mass nouns and plural nouns. As the examples in (35) illustrate, this is indeed the case.
a. mij-n
geld
$m y-a_{\text {SPURIOUS }}$
money
'my money’
b. mij-n
kinderen
my $a_{\text {SPURIOUS }}$
children
'my children'

(standard Dutch)

We implement this analysis by assuming that the pronominal part of this complex possessive pronoun is base generated in the specifier of PosP and the spurious article 
part, reflected by the indefinite gender agreement, is base generated as the head of NumP. Schematically (33a) and (35) can be represented as in (36): ${ }^{12}$

\section{[DP D [PosP mij [Pos, Pos [NumPNum [NP opa/geld/kinderen]]]]]}

\subsubsection{Analysis of strategy 1: a definite article on the remnant of ellipsis}

This subsection is subdivided into three further subsections. The first subsection answers the question what the status of the definite article is and to what extent it acts as a 'regular' definite article. Subsection 2 discusses the reason the definite article pops up in this construction. Finally, subsection 3 provides the analysis of this strategy to deal with possessee ellipsis.

The status of the definite article The way in which strategy 1 deals with ellipsis of the possessee is the following: a definite article appears when the possessee is elided. The question arises why this definite article appears on the remnant of this type of ellipsis. Before we answer this question, we explore the status of the definite article in this construction.

First of all, the definite article can only appear in combination with a possessive pronoun when the possessee is elided. ${ }^{13}$ This is illustrated in example (37).
a. (*de) mijn vader
- de mijne
the my father
the mine
b. (*de) mennen traktor
- de mainn
the my tractor
the mine

(standard Dutch)

(Wambeek Dutch)

Furthermore, the definite article in this construction does not seem to make a semantic contribution: more specifically, it does not seem to add definiteness. An indication for this is that possessive constructions featuring a possessive pronoun are already necessarily definite in Dutch and its dialects (cf. Schoorlemmer 1998). This

\footnotetext{
${ }^{12}$ In Bennis et al. (1998), it is argued that the spurious indefinite article een typically occurs in nominal constructions in which predicate movement has applied (e.g., the constructions in (34)). In line with Den Dikken (1998), Corver (2003, 2008) proposes an analysis of Dutch possessive noun phrases like mijn huis 'my house' in terms of DP-internal predicate movement. The element mij is taken to be an inverted predicate and the element $-n$ in mijn is identified as the spurious indefinite article. In the present paper we will abstract away from the application of DP-internal predicate movement in possessive constructions and simply assume that the possessive pronoun is base-generated in Spec,PosP and the spurious article in Num $^{\circ}$.

${ }^{13}$ The fact that determiners cannot appear in combination with attributively used possessive pronouns holds for almost all dialects of Dutch. There are a few exceptions, namely the dialect of Hooghalen where we have attested the combination of a demonstrative pronoun in combination with an attributively used possessive pronoun, see example (i), and in middle Dutch where postnominal possessive pronouns can cooccur with demonstrative pronouns (Duinhoven 1988), see example (ii).
}

(i) Die mien planten bint dood.

those my plants are dead

'Those plants of mine are dead.'

(Hooghalen Dutch)

(ii) op die hoede sijn

on that gard his

'on his guard'

(Middle Dutch) 
is illustrated by the examples in $(38 \mathrm{a}-\mathrm{c})$, which demonstrate that possessive noun phrases, see (38c), just like definite noun phrases, see (38b), cannot occur as (VPinternal) subjects in presentational/existential constructions. ${ }^{14}$

(38) a. Er is een melkboer langs geweest.

there is a milkman round been

'A milkman came round.'

b. * Er is de melkboer langs geweest. there is the milkman round been

c. * Er is mijn melkboer langs geweest. there is my milkman round been

d. * Er is de mijne langs geweest. there is the mine round been

(standard Dutch)

Finally, the definite article in pronominal possessive constructions behaves differently from other definite articles in that it cannot be replaced by other determiners like demonstrative pronouns (cf. also Den Besten 2007). This is illustrated in (39).

$$
\begin{aligned}
& \text { de / *die mijne } \\
& \text { the / that mine }
\end{aligned}
$$

(standard Dutch)

These characteristics of the definite article in the pronominal possessive construction suggest that the definite article does not have the same status as definite articles in their 'regular' attributive use. We argue in this section that the definite article is indeed not a normal definite article, but that its sole function is to complete the gender specifications on the remnant of ellipsis in order to be able to fully identify the gender features of the elided possessee. Put differently, we claim that in this construction the definite article acts as an agreement morpheme, rather than as a marker of definiteness. ${ }^{15}$

Why a definite article? It might be clear from the discussion in Section 2.1 above that the appearance of the definite article is linked to the gender marking on the possessive pronoun. More particularly, we have shown that if the possessive pronoun does not make all the gender distinctions which are available in the dialect, the definite article has to appear. We argue in this section that a definite article has to appear because the complete inventory of gender specifications has to be overtly and unambiguously present on the remnant of possessee ellipsis. The reason for this is that the position of the possessee is occupied by pro, which needs to be licensed and

\footnotetext{
$\overline{14}$ There are languages in which possessive constructions can also be indefinite. Italian is such a language; see (i) and (ii).

(i) la sua casa

the his house

'his house'

(ii) una sua casa

a his house

'a house of his'

(Italian)

15 The question arises as to what causes the sharp ungrammaticality of determiners in non-elliptical possessive constructions. We refer the reader to Schoorlemmer (1998), who gives an analysis of this difference.
} 
identified by gender agreement (cf. Lobeck 1995, Kester 1996). The gender features of pro, we argue, have to be fully recoverable from the gender marking on the remnant of ellipsis.

If the gender agreement on the possessive pronoun itself is able to uniquely identify the gender specification of the elided possessee, as in Winterswijk Dutch (see examples (10)-(12), repeated in (29) and (32)), the definite article is fully optional. However, if the agreement affix on the possessive pronoun is either not present at all or not able to uniquely identify the gender of the elided possessee, then the definite article is obligatory.

Recall that there are three subtypes of dialects within this strategy in which the definite article obligatorily appears: Asten Dutch, Aalst Dutch and standard Dutch. To see why the definite article is obligatory in these cases, we need to look at them in detail.

First reconsider the examples from Asten Dutch in (7)-(9), repeated in (40)-(42).

(40) a. masculine singular: de oom,

b. feminine singular: de dame,

c. neuter singular: 't kenijn,

d. plural: de pe:rd, nen opa

een oma

een keind geen boeke 'the uncle, a grandfather' 'the lady, a grandmother' 'the rabbit, a child' 'the horses, no books'

(Asten Dutch)
a. masculine singular: min-nen opa
b. feminine singular: min tante
c. neuter singular:
min keind
d. plural:
min keinder

(Asten Dutch)

(42) a. masculine singular: de minnen

b. feminine singular: de $\min$

c. neuter singular: $\quad t$ min

d. plural: de $\min$

'my grandfather'

'my aunt'

'my child'

'my children'

$$
\begin{aligned}
& \text { 'mine' } \\
& \text { 'mine' } \\
& \text { 'mine' } \\
& \text { 'mine' }
\end{aligned}
$$

(Asten Dutch)

This dialect makes a distinction between all three genders: on the indefinite article there is a distinction visible between masculine gender on the one hand and neuter and feminine gender on the other. On the definite article paradigm a distinction is made between neuter gender on the one hand and masculine and feminine gender on the other. As discussed in subsection 3.1.1, the possessive pronouns show the same gender distinctions as the indefinite article. Since the indefinite gender system in this dialect does not make the same gender distinctions as the definite gender system, the possessive pronoun does not make all gender distinctions present in the dialect. As such it is not able to fully identify the gender of all elided possessees: a neuter possessee cannot be identified by the indefinite gender system, since this system does not have a distinct form for the neuter gender. It only has a distinct form for masculine gender. In order to be able to uniquely mark neuter gender, a definite article has to appear, since the definite gender system does have a distinctive form for neuter gender. An interesting aspect of this system is that one might expect that 
the definite article only has to appear when the elided possessee is neuter singular, as the indefinite gender system (visible on the possessive pronoun) is able to uniquely identify masculine gender. This is not the case, however. Apparently, the strategy, once needed for a certain number/gender combination, has to be applied throughout the system. This might very well have to do with learnability. It might be easier for the language learner to just apply the strategy than to calculate for each individual number/gender combination if a definite article is needed.

For Aalst Dutch and standard Dutch a similar analysis holds. In standard Dutch, see the examples in (17)-(19), repeated here in (43)-(45): the indefinite gender system, and hence the possessive pronoun, does not make any distinction for gender.
a. non-neuter singular: de man, een man 'the man, a man'
b. neuter singular:
het kindje, een kindje
'the child, a child'
c. plural:
de kinderen, geen kinderen 'the children, no children'

(standard Dutch)
a. non-neuter singular: mijn opa
'my grandfather'
b. neuter singular:
mijn kind
'my child'
c. plural:
mijn kinderen
'my children'

(standard Dutch)
a. non-neuter singular: de mijne
'mine'
b. neuter singular:
het mijne
'mine'
c. plural:
de mijne
'mine'

(standard Dutch)

In order to be able to fully identify pro, the system has to resort to the definite gender paradigm, and hence to the addition of a definite article, on which the relevant gender distinctions are made. In Aalst Dutch, a dialect which just like Asten Dutch makes a distinction between masculine, feminine and neuter gender, not all possessive pronouns make all the relevant gender distinctions; see example (16), repeated here as (46).

(46) a. masculine singular: eur'n auto oa-n auto 'her car, your car'
b. feminine singular: eur koe oa koe 'her cow, your cow'
$\begin{array}{ll}\text { c. neuter singular: eur kiendj oa kiendj 'her child, your child' } \\ \text { d. plural: }\end{array}$

(Aalst Dutch)

In this type of dialect the definite article also needs to be added to uniquely identify neuter gender. Just as in Asten Dutch it has to be noted that the definite article is not needed to uniquely mark masculine gender on the possessive pronoun. However, just as in Asten Dutch, the rule seems to be that if the definite article is needed to mark gender on the possessive pronoun remnant in some instances of possessee ellipsis, it is obligatory in all instances. 
To summarise, the definite article which appears on the remnant possessive pronoun of possessee ellipsis acts as an agreement marker. It is present to uniquely identify the gender of the elided possessee.

Analysis of strategy 1: a definite article on the remnant of possessee ellipsis In this subsection we present an analysis for dialects using strategy 1 to deal with possessee ellipsis: the obligatory or optional presence of a definite article.

In order to account for these data, we have to make some (quite basic) assumptions. Firstly, we assume, following a vast amount of literature (cf. among others Lobeck 1995, Kester 1996, Sleeman 1996, Schoorlemmer 1998) that there is a pro 'replacing' the elided noun. ${ }^{16}$ Pro has to be formally licensed and identified. Kester (1996), following Lobeck (1995), argues that pro in cases of NP-ellipsis with an adjectival remnant is licensed and identified by the agreement morphology on the adjective. Kester (1996), for instance, discusses ellipsis of a noun modified by an adjective. She shows that the remnant adjective has to carry an agreement affix in order to license and identify the gender features of pro replacing the elided noun. Secondly, we will assume that, just like overt nouns, pro carries a gender feature and a number feature. Both have to be licensed and identified by overt instantiations of these features on the remnant of ellipsis.

Rizzi (1986) proposes a difference between licensing, which is a syntactic condition which requires that pro be governed by agreement features, and identification, which is a semantic condition required for interpretation. Pro has to be identified by the overt gender features on the remnant of ellipsis. Furthermore, we assume that pro (in the DP) is formally licensed in a Spec,Head agreement configuration (cf. Chomsky 1995, Carstens 2000). This second assumption seems quite unfortunate in the light of current ideas concerning agreement in the $\mathrm{CP}$ domain. In most recent versions of minimalist theorizing, the concept of Spec,Head agreement has been abandoned (for argumentation see Chomsky 2001) for another mechanism to establish agreement relations, namely Agree. ${ }^{17}$ It would be preferable if the same agreement mechanism could also be applied to the nominal domain. However, Agree is based on a Probe-Goal system in a bottom-to-top derivation. When a Probe, a head with unvalued features, is merged, it searches its c-command domain for a Goal, an item with the valued counterpart of the Probe's features. This basically means that the unvalued features always have to be structurally higher in the derivation than the valued features. If this agreement mechanism is applied to the

\footnotetext{
${ }^{16}$ Another assumption about noun ellipsis which has been put forth by Panagiotidis (2002) is that the empty category is a covert lexical noun comparable to English one. This lexical covert noun has to be learned only once. The language learner finds out about the existence and featural make-up of a covert lexical noun when it occurs in a DP-internal context that gives the relevant clues (for instance gender agreement). When the language learner has established the existence and featural make-up of this covert lexical noun, it can identify it in other contexts, without the context having to give the relevant clues. We will not use this analysis of noun ellipsis in this paper. It is clear from the discussion on dialects using strategy 1 that the empty category is licensed only in a very strict context of gender specifications. Hence, it is unlikely that the empty category in this case is an empty lexical noun in the sense of Panagiotidis (2002), since these nouns do not require licensing at all. We will briefly come back to Panagiotidis (2002) in Section 3.2.2 below.

${ }^{17}$ However, see Koopman (2001) and Bobaljik and Wurmbrand (2005) for argumentation that Specifier, Head agreement is still needed to account for the full range of agreement phenomena.
} 
nominal domain, the latter property causes problems. Given standard assumptions, the noun is merged first. Arguably, the noun has valued gender features (these features are inherent to the noun) and unvalued definiteness and number features (these features of the noun are dependent on the context). But if the noun is merged first and carries unvalued features, it will never be able to find a suitable Goal in its c-command domain, as the Goal will be higher up in the structure than the noun. An additional assumption is needed to overcome this problem. Since it is not immediately clear how an Agree-based approach can be extended to the nominal domain, we propose a Spec,Head-type of analysis in the present paper.

Before presenting our analysis, we would, finally, like to remark that the general architecture of the noun phrase that we will adopt in this paper is rather standard: the highest functional projection DP (Abney 1987) is separated from the lexical phrase NP by the intermediate functional projections PosP and NumP (cf. Schoorlemmer 1998 and references cited there; see also Van de Craats et al. 2000).

Let us now consider the analysis in (48) and (49) of the examples from Asten Dutch in (8a) and (9a), repeated here as $(47 \mathrm{a} \& b)$, respectively. These analyses are representative for possessee ellipsis in all dialects that have an indefinite gender system, and hence gender agreement on the possessive pronoun.
a. minn-en opa
$m y$-MASC.SING $_{\text {grandfather }}$
'my grandfather'
b. de minn-en
the mine-MASC.SING

(Asten Dutch)

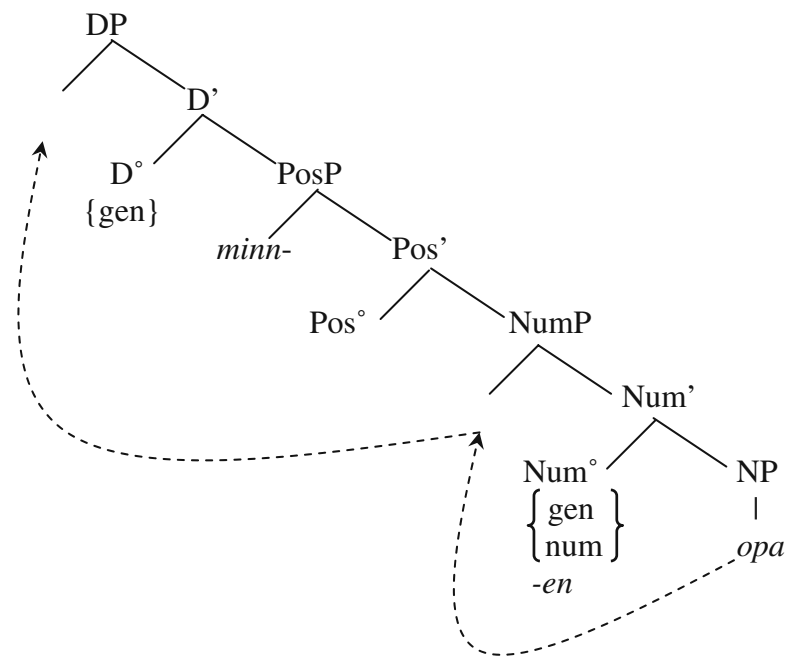

As indicated in (48), the NP opa 'grandfather', is merged with $\mathrm{Num}^{\circ}$, which has number and gender features. As the number feature on the NP is unvalued, it has to raise to Spec,NumP. Hereby, the unvalued gender feature of $\mathrm{Num}^{\circ}$ gets valued. Finally, the gender feature of $\mathrm{D}^{\circ}$ has to be checked. The question arises as to what 
triggers the movement of the NP opa 'grandfather' from Spec,NumP to Spec,DP. One way to go would be to say that the functional category $\mathrm{D}^{\circ}$ is specified for an uninterpretable gender feature that attracts the NP opa 'grandfather' (carrying an interpretable gender feature) to its Spec-position. Since there is no evidence for overt movement of the NP opa 'grandfather' to Spec,NumP and Spec,DP, and the NP occupies - with a few exceptions - the final position in the noun phrase, we assume that these movements take place at LF (indicated by the dotted line).

Now consider the analysis in (49) of the example in (47b).

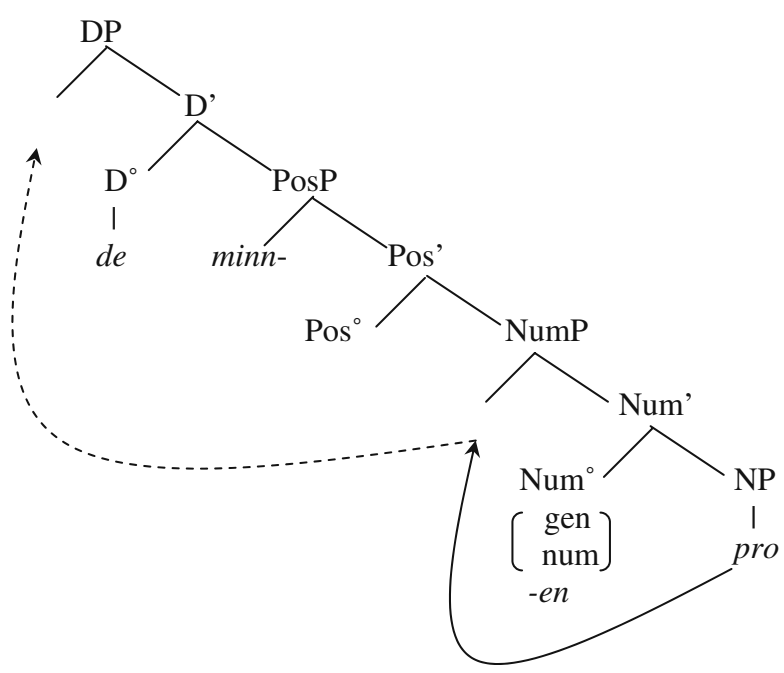

The analysis of the example in (47b) with ellipsis of the possessee is more or less similar to that of the non-elided case discussed in and below (48). The only difference is that the NP is now headed by pro rather than by a lexical noun. Pro needs to be licensed and identified. It gets identified by the overt agreement features on the remnant of ellipsis. The definite article, acting as an agreement marker, needs to be present since the possessive pronoun alone cannot uniquely identify pro.

Furthermore, pro needs to be formally licensed. We assume that formal licensing has to take place before the derivation is sent off to PF, i.e., before Spell-Out. Hence, pro moves overtly to Spec,NumP (indicated by the solid line) to check the number and gender feature of $\mathrm{Num}^{\circ}$. Finally, just as in (48), the gender feature of $\mathrm{D}^{\circ}$ has to be checked. This feature gets checked by movement of pro to Spec,DP. We will take the second movement step, i.e., movement from Spec,NumP to Spec,DP to be an operation that takes place in covert syntax and not in overt syntax, just like the movement step of the NP opa 'grandfather' in the derivation in (48).

Now consider the analysis in (51) of possessee ellipsis in a dialect without an indefinite gender system and hence without gender agreement on the possessive pronoun, like the standard Dutch example in (4), repeated here as (50). ${ }^{18}$

\footnotetext{
${ }^{18}$ Note, by the way, that the analysis of the attributive example is exactly similar to the one of Asten Dutch in (48) discussed above: the NP containing the head noun moves to Spec,NumP to check its number feature. At LF it moves to Spec,DP to check the gender feature of $\mathrm{D}^{\circ}$.
} 
(50) de mijne

the mine

'mine'

(standard Dutch)

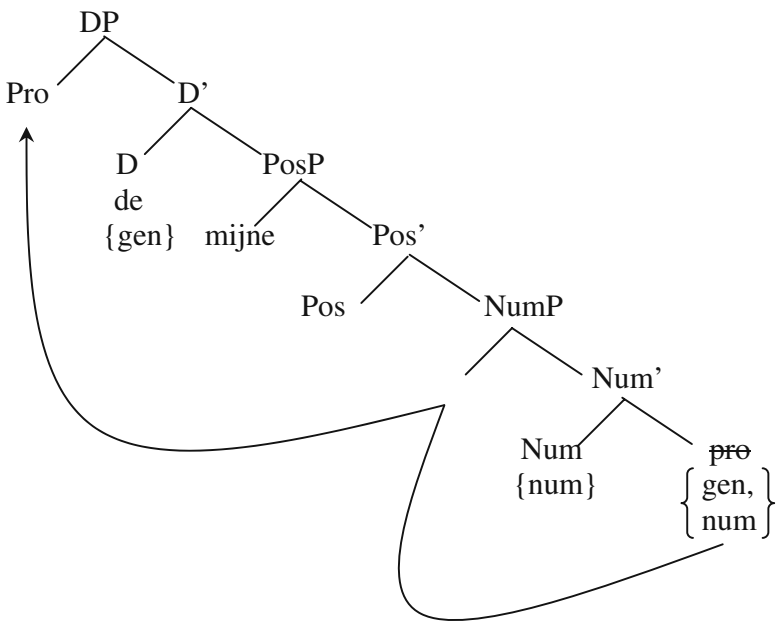

Pro, again, has to be licensed in a Spec,Head configuration by a gender feature. However, as there is no indefinite gender system in this type of dialect, we assume that $\mathrm{Num}^{\circ}$ does not carry a gender feature. This means that the only head carrying a gender feature is $\mathrm{D}^{\circ}$. As a consequence, pro has to move all the way up to Spec,DP in order to be formally licensed. As formal licensing is a syntactic requirement, this formal licensing has to take place before Spell-Out and hence in overt syntax. As indicated in (51), we assume that movement to Spec,DP proceeds via Spec,NumP. In Spec,NumP, the number feature of pro is checked off against the number feature associated with Num. From there, it moves on to Spec,DP, where the gender feature on $\mathrm{D}$ is checked off against the gender feature of pro.

The difference between dialects like standard Dutch and dialects like Asten Dutch boils down to the fact that the former type of dialect does not have an indefinite gender system and hence no gender features on $\mathrm{Num}^{\circ}$, whereas the latter type of dialect does. This means that pro cannot be formally licensed by $\mathrm{Num}^{\circ}$ under $\mathrm{Spec}$, Head agreement in standard Dutch type dialects, whereas it can in dialects of the Asten Dutch type. As a result pro has to overtly move to Spec,DP in the former type of dialect, whereas it remains in Spec,NumP in the latter type. In Section 4 we show that this difference between the dialects in this group corresponds to another quirk of 
possessee ellipsis, namely the availability of possessee ellipsis in the possessor doubling construction. ${ }^{19}$

\subsection{Type-2 dialects: an affix invariant for gender on the remnant of ellipsis}

Recall that we have distinguished two strategies to deal with possessee ellipsis in the pronominal possessor construction in Dutch dialects. The first strategy, whereoptionally or obligatorily - a definite article appears on the remnant of ellipsis, has been discussed in detail in the previous subsection. In this subsection we discuss the second strategy in detail. We first draw a parallel between the affixes appearing in this construction and English one-insertion. Secondly, we argue that these affixes can indeed be seen as pronouns occupying the same position as the lexical possessee. Finally, in subsection 3, we discuss the analysis of possessee ellipsis in the dialects using this strategy.

\subsubsection{The e(n)/s-affix and English one-insertion}

In the dialects under discussion in this subsection, an affix invariant for gender appears on the remnant of possessee ellipsis, i.e., on the possessive pronoun. This affix is either an e/en-affix or an $s$-affix. Reconsider the examples in (21) and (22) from Hindeloopen Frisian, repeated here as (52) and (53).
a. masculine singular: mien aaite
b. feminine singular: mien tante
c. neuter singular:
mien bon
d. plural:
mien bon

'my grandfather'

'my aunt'

'my child'

'my children'

(Hindeloopen Frisian)

\footnotetext{
$\overline{19}$ There are two dialects in our corpus, viz. Borgloon Dutch and Zoutleeuw Dutch, which display a slightly unexpected behavior from our perspective. Just like Asten Dutch, Aalst Dutch and Winterswijk Dutch, these dialects have a three way gender system, namely: masculine versus feminine/plural versus neuter. This three way distinction is also found in the possessive pronominal system (in non-ellipsis contexts): zenne ('his', masc), zen ('his', fem/pl), ze ('his', neut). Given this three way gender distinction, one would expect it to be possible to leave out the definite article from elided possessive noun phrases. That is, the gender specification on the pronouns provides sufficient information to identify the gender property of the elided noun. It turns out that it is indeed possible to leave out the definite article. At the same time, however, the formal distinction between feminine/plural versus neuter disappears. That is, the paradigm of remnant possessive pronouns is as follows: zenne ('his', masc), zen ('his', fem/pl), zen ('his', neut). At the moment, we have nothing insightful to say about what causes the neutralization of the fem $/ \mathrm{pl}$ versus neuter distinction in contexts of ellipsis. Nor do we have an answer to the question as to why ellipsis is permitted in spite of the fact that the gender distinction (fem/pl versus neut) is not formally marked on remnant possessive pronouns in these two dialects.
} 
(53)
a. masculine singular: mien-en
'mine'
uze-s 'ours'
b. feminine singular: mien-en
'mine' uze-s 'ours'
c. neuter singular:
mien-en
'mine'
uze-s
'ours'
d. plural:
mien-en
'mine'
uze-s 'ours'

(Hindeloopen Frisian)

Recall from Section 2.2 that Hindeloopen Frisian and Frisian have an en-affix on singular possessive pronominal remnants of possessee ellipsis and an $s$-affix on plural possessive pronominal remnants. In Frisian, the $s$-affix can also appear in the singular. In Hippolytushoef Dutch the possessive pronominal remnant can either be marked by an $e$-ending or an $s$-ending. In this dialect the choice for the affix seems to be dependent on the morphological shape of the possessive pronoun rather than on the feature specification of the possessive pronoun. The pronouns jullie ' you $_{\text {PLURAL }}$ ' and hullie 'they', which are the only two bisyllabic possessive pronouns in this paradigm, go together with the $s$-affix; the other possessive pronouns are followed by the $e$-affix.

We would like to interpret the complete absence of gender agreement in these dialects as an indication that we are not dealing with the same type of ellipsis in this construction as the one we have discussed in the previous section. More specifically, we would like to claim that in these dialects there is no empty category, i.e., pro, that needs to be licensed by agreement. Rather, we argue that these dialects have the English one-insertion strategy; see (54) for an illustration.

(54) a. John bought a big car and Bill bought a small one.

b. I like this car better than that one.

(English)

We would like to argue that the invariant affix on the remnant of ellipsis is an overt (weak) pronoun replacing the 'elided' part of the noun phrase. Interestingly, these dialects have a construction that at first sight shows a remarkable resemblance to one-insertion in English, illustrated in (55).

$$
\begin{aligned}
& \text { 'n raor-en een } \\
& \text { a strange one } \\
& \text { 'a strange one' }
\end{aligned}
$$

(Hindeloopen Frisian)

Barbiers (2005) provides an in-depth study of one-insertion in Dutch dialects and English. He shows that this phenomenon occurs in Frisian, Groningen Dutch and Brabant Dutch. A subset of these languages, namely only the former two, also have the invariant affix in the possessive constructions under discussion in this paper. Barbiers (2005) convincingly shows that the instance of one appearing in the Dutch/ Frisian one-insertion varieties differs substantially from English one. He discusses four properties in which English one-insertion differs from Dutch/Frisian oneinsertion: (i) In English, one cannot be left out, whereas this is possible in the Dutch/ Frisian varieties, see (56a); (ii) in English there is no adjectival agreement to license an empty category, in the Dutch/Frisian varieties there is, see (56a); (iii) in English but not in the Dutch/Frisian varieties, one can appear in definite constructions, see (56b); and (iv) in English but not in the Dutch/Frisian varieties, one can occur in plural constructions, see (56c). 
(56) a. in rar-en (inne)

a strange *(one)

b. de read-e (*inne)

the red *(one)

c. twee witt-e (*een)

two white*(ones)

(Frisian)

Barbiers argues that these differences can be accounted for under the assumption that in the Dutch/Frisian varieties with one-insertion one does not occupy the $\mathrm{N}^{\circ}$-position, whereas in English it does. In the Dutch/Frisian varieties there is, according to Barbiers, an empty category which is licensed by agreement. The insertion of one in the Dutch/Frisian varieties induces a focus effect.

Although we mainly agree with Barbiers (2005), we would like to argue that in the possessive constructions under discussion in this paper there is no empty category replacing the head noun, but that the en-affix has a function comparable to the pro-form one in English, namely heading the possessive DP. In contrast to een 'one' in Dutch/Frisian one-insertion in the examples in (56), the en-affix appearing on the remnant possessive pronoun in these dialects has the same properties as the pro-form one in English: (i) it cannot be left out, see (57); (ii) there is no agreement marking to license an empty category, see (57); (iii) it can appear in definite constructions (possessive constructions involving a possessive pronoun are typically definite in Dutch and Frisian; see "The status of the definite article" above and cf. Schoorlemmer 1998); and (iv) it can appear in plural constructions; see (57).

$$
\begin{aligned}
& \text { mien bon } \quad \text { - } \text { mien*(-en })^{*} \\
& \text { my children }
\end{aligned}
$$

(Hindeloopen Frisian)

\subsubsection{The status of the e(n)/s-affix}

At this point the question arises as to what the status of the en-affix and the $s$-affix is. Along the line of Postal's (1966) and Déchaine and Wiltschko's (2002) analysis of the English pro-form one, we would like to argue that they are weak pronouns replacing the lexical projection NP. More specifically, we would like to analyze these items as grammatical (i.e., semi-lexical) nouns in the sense of Emonds (1985), i.e., nouns with little descriptive content, just like one, thing and body in English composite pronouns such as someone, something and somebody (cf. also Panagiotidis 2002). Observe that the nominal part of these composite pronouns cannot be phonologically strong either: i.e., *someONE.

Support for the idea that the element -en in mienen (see (57)) is a reduced (i.e., weak) variant of the strong form 'one' (i.e., ain in Groningen Dutch) comes from the observation in Ter Laan (1953:59) that the indefinite pronoun ain (i.e., 'one', 'someone') also has a weak counterpart, which is orthographically represented as $-n$ but pronounced in the same way as $-e n$ in (57). Ter Laan (1953:59) provides the examples in (58).

a. 't Komt aaltied oet, al zel $n$ 't zulf ook oetbringen It comes always out, though will one it oneself also bring-out 
b. Hai is ain van dat soort, doar $n$ aaltied bedrogen mit wegkomt He is one of that type, which one always cheated with away-come

(Groningen Dutch)

Further evidence for the interpretation of $-e n$ as a reduced variant of the full pronominal form ain comes from the examples in (59) drawn from Ter Laan (1953).
a. Ik wil wel geern zo ain/zonent hebben
I want indeed readily so one / so-n-one-t have
'I would really like to have such a one'
b. Wat veur ain / watveurent hest 't laiste?
What for one / what-for-one-t have-you most preferably
'What kind do you prefer most?'
c. Gainain / Gainent zol dat doun
Noone / no-one-t will that do
'No one will do that.'

(Groningen Dutch)

In each of these examples, the pronominal pattern featuring the phonologically strong form ain has a counterpart containing a weak form $-e n .^{20}$ The fact that en occurs in the same structural environment as ain, i.e., in a position following determiner- or quantifier-like elements, is consistent with its NP-status. ${ }^{21}$

As pointed out above, we would also like to argue that the bound morpheme $-S$ that appears attached to the remnant possessive pronoun is a pro- $\mathrm{N}(\mathrm{P})$ as well (see, e.g., the paradigms in Section 2.2 above). The question arises as to what evidence there is for the pro-N(P) status of $-s$. Some suggestive support for this analysis of $-s$ comes from the existence of other nominal construction types featuring the element $-s$. Consider for instance the constructions in (60).
a. iets mooi-s
something beautiful-s
'something beautiful'
b. tot zien-s / tot bloeden-s toe
until see-s until bleed-s until
'see you/until it bleeds'
c. van klein-s/jong-s af aan
from small-s/young-S PART on
'from the time we were small/young'

(Dutch)

In these examples, the $s$-ending has a nominalizing effect. Attachment of $-s$ to the infinitival verbs zien 'see' and bloeden 'bleed' in (60b) and to the adjectives klein

\footnotetext{
${ }^{20}$ The $-t$ at the end of the pattern featuring the reduced pro-form -en is the so-called paragogic $-t$. We refer the reader to Corver and Van Oostendorp (2005) for a discussion of paragogy of [t] after coronal sonorants such as $l, n$, and $r$.

${ }^{21}$ It should be noted that the full form ain in Groningen Dutch never combines with a possessive pronoun. Thus: *mien-ain versus mien-en-t (my-one-t). At the moment, we do not have an account for this asymmetry between remnant possessive pronouns and attributive pronouns.
} 
'small' and jong 'young' in (60c) results in a nominal form. The nominal status is clear from the distribution of the forms ziens, bloedens, kleins and jongs; they occur as complements of prepositions, which typically take noun phrases as their complement.

The forms ending in $-s$ in $(60 \mathrm{~b}, \mathrm{c})$ are 'lexically fixed' and might very well be stored in the lexicon. This seems less likely for the (productive) 'partitive' construction in (60a), where the $-s$ follows an adjectival element. ${ }^{22}$ As exemplified in $(61 \mathrm{a}, \mathrm{b})$, the word mooi 'beautiful' can be modified by degree words such as vreselijk 'extremely', erg 'very', et cetera, and can have a comparative adjectival form (i.e., A+ -er). This suggests that mooi is a true adjective. Another fact that shows that the element to which $-S$ attaches is a truly adjectival element comes from the pattern in (61c). In this pattern, we have a noun phrase complement to the left of onbekend $+s$. If onbekends were a derived nominal category, then the presence of the noun phrase complement to the left of onbekends would be totally unexpected, given the fact that a noun never takes a noun phrase complement to its left in Dutch. Thus, mij must be the object of the adjective onbekend.
a. iets [vreselijk/erg moois]
something extremely/very beautiful-s
'something extremely/very beautiful'
b. iets [veel mooi-er-s]
something much beautiful-COMPAR-s
'something much more beautiful'
c. Er werd [iets [mij (volledig) onbekends]] gespeeld.
There was something me (completely) unknown-s played
'They (e.g. the violinists) played something which was (completely) unknown to me.'

(Dutch)

The next question that arises concerns the $-s$ ending that follows the adjective (e.g., mooi in (60a)): Is it an (inflectional or derivational) suffix that attaches to $\mathrm{A}^{\mathrm{o}}$, or is it some other grammatical element, e.g. an enclitic (nominal) element that cliticizes onto an immediately preceding adjective. As already stated above, we would like to claim that $-S$ is a grammatical morpheme that substitutes for $\mathrm{N}(\mathrm{P})$. Although it is quite hard to find conclusive evidence for one or the other analysis, we would like to point out that examples such as those in (62) have been observed in Royen (1948:42).
a. iets klein en verachtelijks
something small and despicable-s
'something small and despicable'
b. iets schijnbaar zeer klein en tengers
something apparently very small and slight-s 'something apparently very small and slight'

(Dutch)

\footnotetext{
${ }^{22}$ According to Royen (1948:32), these so-called partitive genitive constructions originally involved assignment of genitival case. He argues that in present-day Dutch, the $-s$ should no longer be interpreted as a genitival case suffix. It rather constitutes an element that 'assigns' nominal status to an adjective.
} 
What is interesting about these examples is that $-S$ attaches to the last nominal element of a pattern consisting of two coordinated adjectives, e.g. [klein en verachtelijk $]+s$. If $-s$ were a true inflectional suffix, then it would always have to be attached to both coordinated adjectives, given the fact that inflectional suffixes typically do not attach to a single member (e.g., the rightmost one) of two coordinated nouns (e.g. Dutch: *veel [jongen en meisje]-s; many [boy and girl]-s 'many boys and girls'; OK veel [jongen-s en meisje-s]).

The occurrence of the patterns in (63) in colloquial Dutch does not seem to be compatible with an analysis of $-s$ as an inflectional (or derivational) suffix (examples drawn from the internet with the aid of Google).

(63) a. Als ik niets te doen heb, vind ik meestal wel [iets goed genoegs] op tv When I nothing to do have, find I mostly PRT something good enough-s on TV 'When I have nothing to do, I usually find something on TV.'

b. Je bent gek genoeg om mij met [iets gek genoegs] op te schepen.... You are stupid enough for me with something crazy enough-s up to put 'You are crazy enough to put me up with something crazy enough.'

c. Moeten ze eerst maar eens [iets koel genoegs] maken Must they first PRT once something cool enough-s make 'They should first make something which is cool enough.'

The $-S$ in these examples occurs to the right of the adverbial element genoeg 'enough'. So, it does not appear attached to the adjectival element (i.e., *iets groots genoeg; something big-s enough 'something big enough'). The fact that $-s$ appears to the right of the complex adjective phrase groot genoeg suggests that $-s$ is not a suffixal element.

As suggested above, we will assume that $-S$ is a clitic-like element that substitutes for $\mathrm{N}(\mathrm{P})$. The structure of iets mooi-s then looks as follows: ${ }^{23,24}$

$$
\text { iets }\left[{ }_{F P}\left[{ }_{A P} m o o i\right]\left[F^{\prime} F\left[{ }_{N P}-s\right]\right]\right]
$$

To summarise, in this subsection we have discussed the status of the $e(n) / s$ affixes. We have argued that both can be regarded as pronominal (enclitic) elements

\footnotetext{
${ }^{23}$ We abstract away here from the exact nature of the structural relationship between iets and moois.

${ }^{24}$ An anonymous reviewer points out that standard Dutch might also be expected to make use of this strategy as it also has the $s$-ending at its disposal. We do not want to go into this in great detail here, but it is indeed the case that this strategy is in fact used in colloquial Dutch. Consider the example in (i).

(i) mijn vader - mijn-es

my father mine

(colloquial Dutch)

When the possessee vader 'father' is elided in colloquial Dutch, then apart from the form de mijne 'mine' discussed extensively in Sections 2.1 and 3.1 above, the form mijnes 'mine' is also found. This form clearly ends in the $s$-affix which is identified in this section as a pro-NP replacing the possessee.
} 
replacing a lexical NP. ${ }^{25}$ The question that remains to be answered is why the dialects using this strategy have more than one affix at their disposal. It seems to be the case that the lexicons of these dialects just have more than one lexical item available to replace lexical NPs with different feature specifications. For instance in Frisian and Hindeloopen Frisian, the en-affix is associated with singular and the $s$-affix with either just plural (in Hindeloopen Frisian) or both singular and plural (in Frisian). Presumably this has something to do with the lexical item the pro-NP is derived from. If en, for instance, is indeed similar to English one in one-insertion contexts, as argued in (59) above, one might expect it to be restricted to singular contexts.

\subsubsection{Analysis of strategy 2: an e(n)/s-affix on the remnant of possessee ellipsis}

After this digression on the status of $-e(n)$ and $-s$, let us get back to the main point of this subsection: if the en-affix, and also the $-s$-affix, is actually a 'dummy' noun replacing the lexical $\mathrm{N}(\mathrm{P})$, then there is no empty category (i.e., pro). More specifically, there is no pro that needs to be licensed by gender agreement through Spec,Head-agreement. This means that the analysis of examples like those in (53) from Hindeloopen Frisianbut the same holds for the examples in (27) from Frisian and (26) from Hippolytushoef Dutch - is similar to the analysis of the example with an attributive possessive pronoun in Asten Dutch in (47) provided in (48). Consider the analysis in (66) of the example in (53a), repeated here as (66), from Hindeloopen Frisian.

$$
\text { masculine singular: mien-en 'mine' }
$$

(Hindeloopen Frisian)

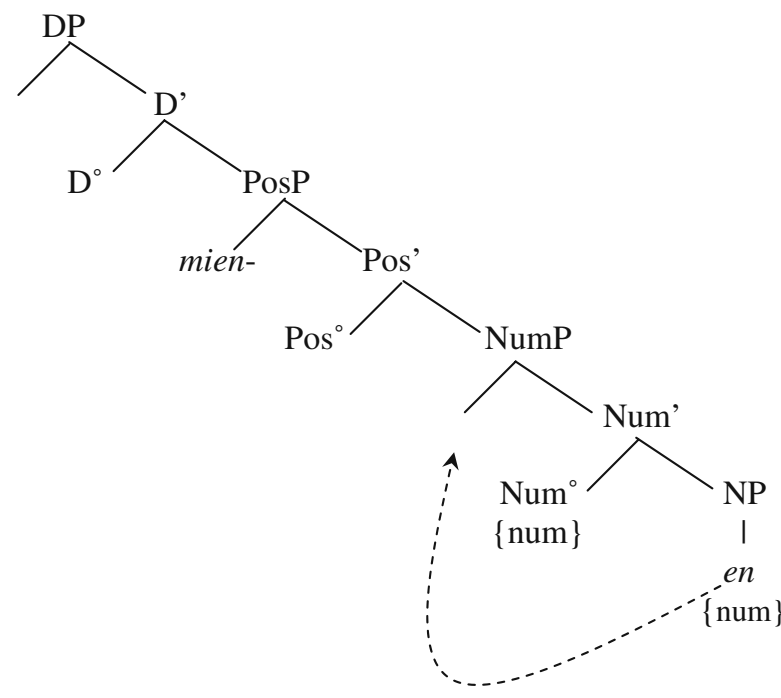

\footnotetext{
${ }^{25}$ We have identified $e(n)$ and $s$ as enclitic pro-forms. So, strictly speaking, they are clitics, i.e. grammatically independent but phonologically dependent words; i.e., they occupy an independent syntactic base position and get phonologically attached to a (preceding) host. In this respect, these morphemes are comparable to the English possessive clitic $-s$, as in the boy next door's bike. It is generally assumed that the possessive morpheme occupies a functional head position (e.g., D or Pos) and phonologically attaches to the final word of the phrase occupying the Spec-position of $-s$. Even though we consider $e(n)$ and $s$ to be enclitic pronouns, we will nevertheless keep on referring to them as 'affixes' in the main text, although this label is mostly used for derivational and inflectional morphemes attached to a stem to form a word.
} 
In Hindeloopen Frisian there is a pro-NP en in the singular. This NP, just like the lexical NP in the Asten Dutch derivation in (48), moves to Spec,NumP to check its number feature. Since we have no arguments to the contrary, we will assume for now that the en-affix moves covertly to Spec,NumP (indicated by the dotted line). The $e n$-affix, just like the $s$-affix and the $e$-affix used in these dialects, is not specified for gender. It appears irrespective of the gender of the possessee. We take this to mean that these affixes do not carry gender features. However, the en-affix in Frisian and Hindeloopen Frisian seems to be specified for number, as it only appears in singular contexts.

The difference between this second strategy to deal with possessee ellipsis and the one discussed in the previous section is that in this case there is no pro which needs to be licensed. As a consequence, gender agreement does not play a role on the remnant of possessee ellipsis in dialects using this strategy and hence there is also no need for the appearance of the definite article, which we argued acts as an agreement marker in this construction. Furthermore, there is also no reason to assume that the pro-NP in this dialect moves all the way to Spec,DP at LF, at least not in overt syntax. Recall that the reason to assume that in dialects like standard Dutch pro moves to Spec,DP is because this is the only position in the structure where it can be formally licensed by gender features. This means that dialects like Hindeloopen Frisian and Hippolytushoef Dutch pair up with dialects with an indefinite gender system like Asten Dutch, Aalst Dutch and Winterswijk Dutch, in which pro can be formally licensed in Spec,NumP. In both types of dialect Spec,DP is not filled in overt syntax. The relevance of this overlap between the dialects using strategy 2 on the one hand and dialects with an indefinite gender system on the other will become clear in Section 4.

\subsection{Summary}

In this section we have theoretically implemented the empirical generalizations concerning ellipsis in possessive constructions as discussed in Section 2. For dialects using strategy 1 we have argued that there is an empty pro 'replacing' the possessee. This pro has to be licensed and identified. It is identified by realizing the full range of gender specifications on the remnant of possessee ellipsis. Since the possessive pronoun reflects the indefinite gender system and this gender system usually does not specify all gender specifications in the dialect, often the definite article, realizing the definite gender system, has to be added. It is not acting as a regular definite article, but merely as a marker of the definite gender system in this construction. The dialects using this strategy differ in one respect, namely, whether or not the dialect has an indefinite gender system, visible on the possessive pronoun and the indefinite article. If a dialect has an indefinite gender system, pro can be formally licensed by the gender features in $\mathrm{Num}^{\circ}$ (the host of the indefinite gender system). In these dialects pro does not have to move all the way to Spec,DP to be formally licensed by the definite gender features in $\mathrm{D}^{\circ}$ (in overt syntax). However, if a dialect does not have an indefinite gender system, then $\mathrm{Num}^{\circ}$ does not have gender features. In those dialects, pro has to move to Spec,DP to be formally licensed by the gender features in $\mathrm{D}^{\circ}$.

Dialects using the second strategy under consideration in this article actually do not have ellipsis of the possessee in the strict sense of the word. The NP-position is 
not occupied by an empty category, but by a pro-NP. This pro-NP is realized as an $e$ $(n) / s$-affix on the possessive pronominal remnant. In these dialects there is no gender marking at all on the remnant of ellipsis, since there is no pro that needs to be licensed. Therefore, the definite article, acting as an agreement marker in this construction, also does not have to appear. In these dialects Spec,DP also remains available for other constituents since nothing moves to it in overt syntax.

\section{Ellipsis with a doubling possessor as remnant: three types of dialects}

In the previous sections we have discussed ellipsis in the pronominal possessor construction. This section provides an argument in favour of the analyses of this type of ellipsis on the basis of ellipsis in the possessor doubling construction. An example of the possessor doubling construction is provided in (1b), repeated here as (67). ${ }^{26}$

John z'n auto
John his car
'John's car'

possessor doubling construction

'John's car'

(standard Dutch)

Dialects differ as to whether and how they allow ellipsis with an XP-possessor as remnant. The examples in (68)-(71) illustrate this point. Standard Dutch, example (68), does not allow ellipsis in the possessor doubling construction. In Hindeloopen Frisian, Asten Dutch and Winterswijk Dutch, illustrated in (69), (70) and (71) respectively, ellipsis of the possessee is possible in this construction. The restrictions on the appearance of the definite article in this construction are exactly similar to those discussed in Sections 2 and 3 above, so we will not go into that any further here.

(68) (Over auto's gesproken / Talking about cars)

ik vind (*Teun) de zijne echt geweldig

I find Teun the his really great

'I find Teun's really great.'

(standard Dutch)

(69) (Over auto's gesproken / Talking about cars)

ik vein Teun *(de) zinnen echt geweldig

I find Teun the his really great

'I find Teun's really great.'

(Asten Dutch)

(70) Vonnebos (de) zien-e

Vonnebos (the) his -FEM.SG $_{\text {. }}$

'Vonnebos's (e.g. Vonnebos's car)'

(Winterswijk Dutch: Deunk 1977)

(71) Jan sienen

Jan his

'Jan's (e.g. Jan's car)'

(Hindeloopen Frisian)

We will argue that the dialects using the first strategy to deal with possessee ellipsis, i.e., those that have genuine ellipsis and identify the empty category pro by

\footnotetext{
${ }^{26}$ The possessor doubling construction is restricted to third person (singular and plural) possessors.
} 
gender agreement on the remnant of ellipsis, have to be further divided into two subgroups. The first subgroup, represented by the standard Dutch example in (68), does not allow ellipsis in this construction, whereas the second one, represented by Asten Dutch and Winterswijk Dutch in examples (68) and (70), respectively, does. In the dialects using the second strategy, represented by Hindeloopen Frisian in example (71), ellipsis in the possessor doubling construction is possible.

\subsection{Type 1 dialects: a definite article on the remnant of ellipsis}

As already noted above, the dialects using the first strategy identified in Section 2.1 above have to be further divided into two groups: those that allow ellipsis in the possessor doubling construction and those that do not. Interestingly, the possibility of having ellipsis in this construction correlates with the presence of gender agreement on the possessive pronoun. The examples in (72) and (73) illustrate this. In standard Dutch, ellipsis cannot take place in the possessor doubling construction, see example (68), and the possessive pronoun does not show gender agreement, see example (72). However, in Asten Dutch and Winterswijk Dutch, ellipsis is possible (cf. examples (69) and (70)) and the possessive pronoun agrees in gender with the possessee (cf. examples (73) and (74)).
a. non-neuter singular: mijn man
'my man'
b. neuter singular:
mijn kindje
'my child'
c. plural:
mijn kinderen
'my children'
(73) a. masculine singular:

$\begin{array}{ll}\text { minnen opa } & \text { 'my grandfather' } \\ \text { min tante } & \text { 'my aunt' } \\ \text { min keind } & \text { 'my child' } \\ \text { min keinder } & \text { 'my children' }\end{array}$

(standard Dutch)

(Asten Dutch)

(74) a. masculine singular:

mien-en hood
mien-e mutse
mien hoes
mien-e mutsen

'my hat'

'my bonnet'

'my house'

'my bonnets'

(Winterswijk Dutch: Deunk 1977)

Recall that in Section 3.1 above we made a distinction between definite and indefinite gender. Definite gender is related to the definite article and indefinite gender to the possessive pronoun and the indefinite article. We have argued that definite gender is encoded on $\mathrm{D}^{\circ}$ (the locus of the definite article), whereas indefinite gender is present on $\mathrm{Num}^{\circ}$ (the locus of the indefinite article). The generalisation discussed above, which stated that only dialects which have gender agreement on the possessive pronoun can have ellipsis in the possessor doubling construction, can be reformulated in the following way:

(75) Dialects that have an indefinite gender system (i.e., gender marking on the indefinite article and the possessive pronoun), and hence have gender features on Num ${ }^{\circ}$, allow ellipsis in the possessor doubling construction. 
This generalisation can fairly easily be implemented given the analysis of possessee ellipsis in the pronominal possessor construction discussed above and hence it provides an argument in favour of this analysis.

Recall that in Section 3.1 above, we also argued that the ellipsis site in the dialects under discussion in this section contains a pro. This pro has to be licensed and identified by gender features inside the DP. We have argued that pro in dialects like Asten Dutch and Winterswijk Dutch is licensed in Spec,NumP, because Num ${ }^{\circ}$ in these dialects carries gender features. However, in standard Dutch (a dialect without an indefinite gender system) $\mathrm{Num}^{\circ}$ does not contain gender features and pro has to move overtly to Spec,DP to be formally licensed by the gender features of $\mathrm{D}^{\circ}$. As we already mentioned above, the difference between dialects like Asten Dutch and Winterswijk Dutch on the one hand and standard Dutch on the other is that Spec,DP is only occupied by pro in the latter type of dialect. This means that in the former type of dialect Spec,DP is available to host other constituents.

When we assume that the doubling possessor occupies Spec,DP (cf. Corver 1990, Haegeman 2003 for argumentation), then the difference between the Asten Dutch type dialect and the standard Dutch type concerning ellipsis in the possessor doubling construction becomes straightforward. We have provided the derivation of the standard Dutch example (68) in (76) and the derivation of the Asten Dutch example (69) in (77).

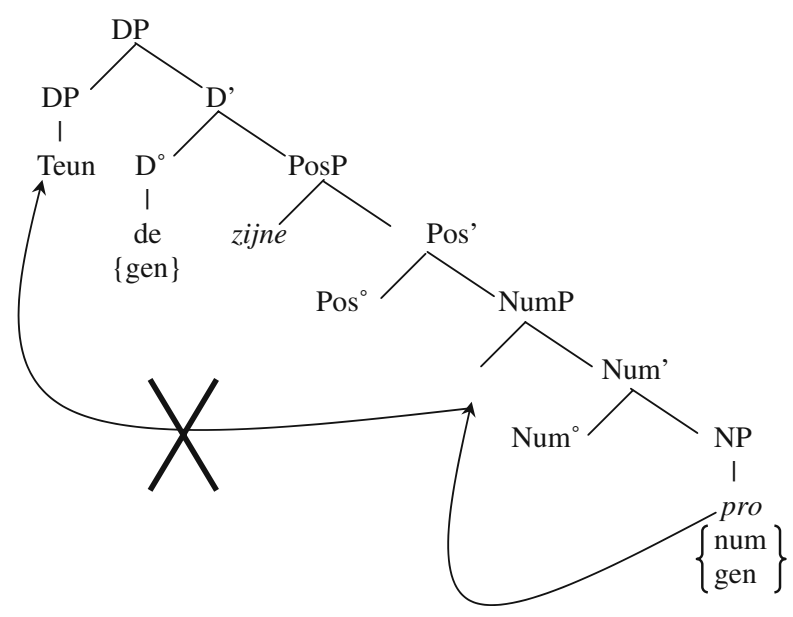

In standard Dutch Spec,DP is occupied by pro which moves overtly to Spec,DP in order to be formally licensed by the gender features of $\mathrm{D}^{\circ}$. Hence, Spec,DP cannot host an additional phrasal possessor like Teun in this position; cf. (68). ${ }^{27}$ In other words, the doubling possessor Teun and the displaced pro compete for the same structural position, viz. Spec,DP.

\footnotetext{
${ }^{27}$ We assume that the Dutch DP does not permit multiple specifiers in overt syntax. However, as argued in note 28 below, we do assume multiple specifiers are available in covert syntax.
} 


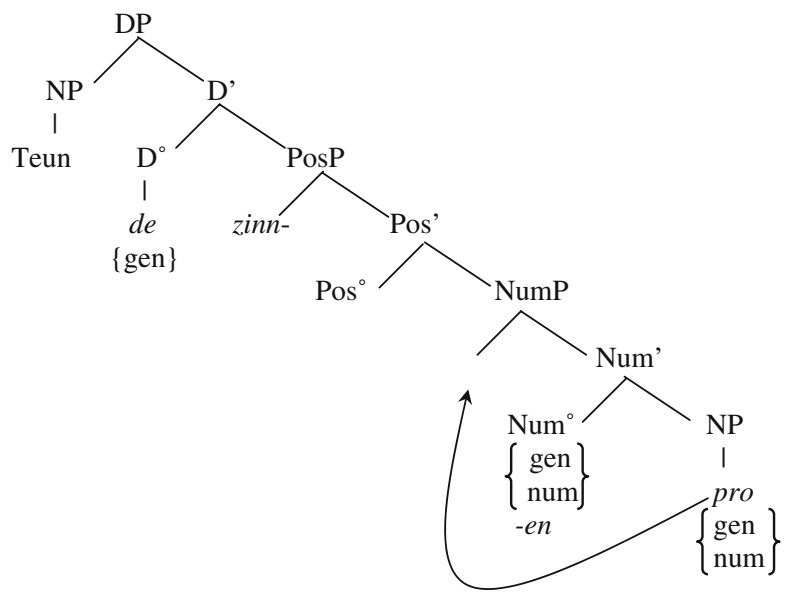

In Asten Dutch, see the derivation (77), pro is licensed in Spec,NumP by the gender features of $\mathrm{Num}^{\circ}$ and hence does not move to Spec,DP in overt syntax. As a consequence, Spec,DP is available for external merger of a phrasal possessor (e.g., Teun in example (69) from Asten Dutch). ${ }^{28}$

This analysis of ellipsis in the possessor doubling construction makes two predictions. First, it should be possible to have ellipsis in the possessor doubling construction in dialects with the second strategy to deal with possessee ellipsis, since in those dialects Spec,DP is also available for external merger in overt syntax. This prediction is borne out, as will be shown in the next subsection. Secondly, this analysis predicts that possessor doubling should be possible in dialects like standard Dutch when the possessee is not elided. The reason for this is that Spec,DP is not filled in overt syntax in those cases. This prediction is indeed confirmed by the data as illustrated in example (67) above.

\subsection{Type 2 dialects: an invariant ending on the remnant of ellipsis}

In the type 2 dialects an invariant ending appears on the remnant of ellipsis. This ending can be either an $e(n)$-affix (see example (21), repeated here as (78), from Hindeloopen Frisian) or an $s$-ending (see Section 2.2 above).
a. masculine singular: mien aaite 'my grandfather' - mien-en
'mine'
b. feminine singular: mien tante 'my aunt'
- mien-en 'mine'
c. neuter singular:
mien bon 'my child'
- mien-en
'mine'
d. plural:
mien bon 'my children'
- mien-en 'mine'

(Hindeloopen Frisian)

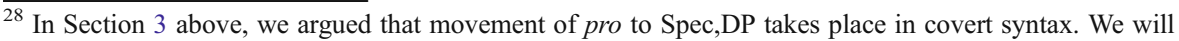
assume that movement of pro to a second Spec-position of D is possible only in covert syntax. Compare in this respect the phenomenon of wh-movement in a language like Dutch: only a single wh-phrase can move to Spec,CP in overt syntax. In covert syntax, though, more than one wh-phrase is moved to the left periphery of the CP, e.g. in multiple wh-constructions like Wie kocht wat? 'Who bought what?'.
} 
When possessee ellipsis is applied to the possessor doubling construction, the same affix appears on the remnant of ellipsis as in possessee ellipsis in the pronominal possessor construction. This is illustrated for Hindeloopen Frisian in (79).
(Over auto's gesproken...)
(Talking about cars....)
Jan sien-en
John his 'John's'
(Hindeloopen Frisian)

Recall that we have argued above that in these dialects there is no pro replacing the possessee. Hence, pro also does not have to be licensed by gender features. Rather, there is a pro-NP, in the form of an affix. This pro-NP behaves like a normal lexical NP. This means that it moves covertly to Spec,NumP to check its number feature. Movement to Spec,DP does not take place (at least not in overt syntax) in this dialect. Consequently, Spec,DP is available to host an externally merged doubling possessor. This means that dialects like Hindeloopen Frisian behave similarly to dialects like Asten Dutch and allow ellipsis in the possessor doubling construction.

\subsection{Summary}

We have shown in this section that not all dialects allow ellipsis in the possessor doubling construction. The dialects using the first strategy to deal with possessee ellipsis, namely an empty category pro replacing the possessee, can be divided further into two groups. Dialects that have gender marking on the possessive pronoun allow ellipsis in the possessor doubling construction; those that do not have gender marking on the possessive pronoun also do not allow for possessee ellipsis in this construction. The dialects which make use of the second strategy and replace the possessee with a pro-NP in the form of an affix also allow ellipsis in the possessor doubling construction. The table in (80) summarises the findings of this section.

\begin{tabular}{llll}
\hline & standard Dutch & Asten/Winterswijk & Hindeloopen/Hippolytushoef \\
Pron.poss ellipsis & Type 1 & Type 1 & Type 2 \\
Poss.doubl. ellipsis & No & Yes & Yes \\
\hline
\end{tabular}

We have argued that this pattern of ellipsis in the possessor doubling construction actually provides an argument in favour of the analysis of possessee ellipsis provided in the previous section. There we argued that the standard Dutch type of dialect differs from the Asten/Winterswijk type of dialect in that in the former type pro has to move to Spec,DP in order to be formally licensed. In the latter type of dialect, pro can be licensed by the indefinite gender agreement features in Num ${ }^{\circ}$. This means that only in the former type of dialect is Spec,DP filled and not available to host the doubling possessor.

Dialects of the Hindeloopen/Hippolytushoef type, i.e., dialects using strategy 2, also allow ellipsis in the possessor doubling construction, as in this type of dialect $\mathrm{Spec}, \mathrm{DP}$ is also free to host the doubling possessor. 


\section{Summary and conclusions}

In this paper we have identified two strategies that are used in dialects of Dutch to leave the possessee in the pronominal possessor construction and the possessor doubling construction unpronounced. The first one uses pro, the second one a proNP. These different strategies result in different syntactic behaviour.

In the first type of dialects the remnant of possessee ellipsis has to be able to identify the gender features of pro. In most dialects the gender specifications on the possessive pronoun are not sufficient to uniquely identify the gender specification of the elided noun. The reason for this is that in many dialects there are two positions in the DP that express gender: the definite gender system and the indefinite gender system. In many dialects these two gender systems do not make the same distinctions: they are often complementary. This means that for unique identification of the gender features of pro both gender systems have to be overtly realized. The indefinite gender system is visible on the possessive pronoun. In order to make the definite gender system visible, many dialects add a definite article to the remnant of ellipsis.

Pro also has to be formally licensed. There are two possibilities: (i) pro is licensed by gender on $\mathrm{D}^{\circ}$ by moving to Spec,DP (definite gender system) or (ii) pro is licensed by gender on $\mathrm{Num}^{\circ}$ by moving to Spec,NumP (indefinite gender system). The former option is only used in dialects without an indefinite gender system, and hence without gender features on $\mathrm{Num}^{\circ}$. If pro does not have to move to Spec,DP in order to be formally licensed, ellipsis with a doubling phrasal possessor is possible, since Spec,DP is available to host an externally merged phrasal possessor.

In the second type of dialect there is no ellipsis of the possessee; rather, there is a pro-NP. This pro-NP, comparable to English one in one-insertion contexts, is realized as an $e(n) / s$-affix in the dialects of Dutch. In these dialects no licensing and identification takes place (since there is no pro) and hence gender does not have to be expressed on the remnant of possessee ellipsis. This means that these dialects also do not add a definite article to the remnant of possessee ellipsis. The dialects using this strategy also allow for doubling of the possessive pronoun when the possessee is 'elided'.

The question arises whether these two types of strategies are unique to the Dutch dialects or whether they are also attested in other languages. In this respect, we have already mentioned English. English seems to have the same strategy for noun ellipsis as we see in the Dutch dialects using the second strategy: a pro-NP replacing the possessee (cf. Section 3.2 above). However, when we look at ellipsis in the pronominal possessor construction in English, then we find a context where we at first sight do not find one-insertion; see example (81) which provides the complete paradigm of possessive pronouns with and without ellipsis of the possessee in this language.

$\begin{array}{llll}\text { (81) a. my car } & \text { mi-ne } & (* \text { one }) \\ \text { b. your car } & \text { your-s } & (* \text { one }) \\ \text { c. his car } & \text { hi-s } & \left(*^{*} \text { one }\right) \\ \text { d. her car } & \text { her-s } & \left({ }^{*} \text { one }\right) \\ \text { e. our car } & \text { our-s } & (* \text { one })\end{array}$




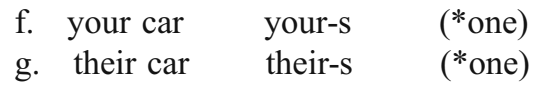

(English)

There are two things that are noticeable about this paradigm. First of all, it shows that one cannot be inserted here. Secondly, the form of the attributive possessive pronoun is considerably different from the substantially used possessive pronoun. When this paradigm is compared to the paradigm of the Dutch dialects using strategy 2, i.e., an affix on the possessive pronominal remnant of possessee ellipsis, it is clear that there is a striking similarity between these dialects and English. In both cases an $n$ - or $s$-ending follows the possessive pronoun. What we would like to claim is that English actually has the same strategy as Hindeloopen Frisian, Hippolytushoef Dutch and Frisian: there is an affix on the remnant of ellipsis which acts as a pro-NP. Furthermore, the variation we find in the variants of Dutch with respect to the combination of possessive pronoun and $n / s$-affix (e.g., the difference between Hindeloopen Frisian and Hippolytushoef Dutch discussed in Section 2.2 above), is also attested in dialects of English. For instance, there are English dialects in which the possessive pronouns yours and his are not followed by a $s$-affix, but rather by a $n$-affix, see example (82).

(82) his-n, your-n (English dialects: Wakelin 1972, Wolfram and Schilling-Estes 1998)

German and French display patterns that are more closely related to the first strategy found in the Dutch dialects, i.e., gender marking on the remnant of possessee ellipsis. First consider French, which is strikingly similar to Aalst Dutch. In French, the possessive pronoun agrees in gender with the possessee, just like in Aalst Dutch. Consider the table in (83) which provides the paradigm of the possessive pronoun when the possessee is present.

\begin{tabular}{llll}
\hline & Masculine & Feminine & Plural \\
my & mon & ma & mes \\
your (sing., fam.) & ton & ta & tes \\
his, her, its & son & sa & ses \\
our & notre & notre & nos \\
your (plur., form) & votre & votre & vos \\
their & leur & leur & leurs \\
\hline
\end{tabular}

The French attributive possessive pronouns make a distinction between masculine and feminine gender. Furthermore, there is a separate form for the plural. We find the same distinction when we look at the definite and indefinite article system: there is a distinction between masculine and feminine in the singular and there is a separate form for the plural. This means that French distinguishes between masculine and feminine and singular and plural. This distinction is present on a subset of the possessive pronouns in the paradigm, but not on all possessive pronouns. As is 
illustrated in (83), the plural possessive pronouns do not mark gender in the singular. If the possessee is elided in this language, then just like in Aalst Dutch a definite article obligatorily appears. This is illustrated in (84).

\begin{tabular}{lllll}
\hline & Masc & Fem & Masc-PI & Fem-PI \\
mine & le mien & la mienne & les miens & les miennes \\
yours (sing, fam) & le tien & la tienne & les tiens & les tiennes \\
his/hers/its & le sien & la sienne & les siens & les siennes \\
ours & le nôtre & la nôtre & les nôtres & les nôtres \\
yours (plur, form) & le vôtre & la vôtre & les vôtres & les vôtres \\
theirs & le leur & la leur & les leurs & les leurs \\
\hline
\end{tabular}

The definite article in French is obligatory for the same reason it is obligatory in Aalst Dutch: not all possessive pronouns make all the relevant gender/number distinctions and hence a definite article has to be added to uniquely identify the gender/number features of pro. In this language it also seems to be the case that, if the definite article is necessary in one gender/number combination, it is obligatory for all possessive pronominal remnants.

Finally, let us look at German. This language is interesting, since it uses the same strategy as Aalst Dutch and French, but in a slightly different way. Consider the examples in (85) from standard German.
a. mein Auto mein-s

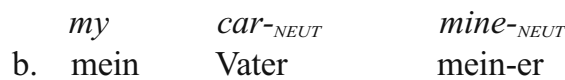

(standard German)

Standard German, just like Aalst Dutch, makes a distinction between masculine, feminine and neuter. When the possessive pronouns are used attributively, i.e., when the possessee is not elided, the weak adjectival inflection is visible on the possessive pronoun. This paradigm does not make all the gender distinctions: it does not mark the difference between neuter and masculine. However, when the possessee is elided, then the strong adjectival inflection is used. This inflection does make the difference between neuter and masculine gender visible. Standard German, like French and the Dutch dialects using the first strategy, have a pro replacing the possessee. This pro is licensed and identified by phi-features. In French and dialectal Dutch these phi-features are expressed by adding a definite article (acting as an agreement marker) to the possessive pronominal remnant of possessee ellipsis. In German, these phi-features are expressed by making use of the strong agreement paradigm. 
To conclude, the strategies identified for possessee ellipsis in Dutch dialects are also attested in other languages such as English, French and German. English uses the same strategy as Frisian, Hippolytushoef Dutch and Hindeloopen Frisian. German and French, on the other hand, seem to adhere to the same strategy as Asten Dutch, Aalst Dutch, Winterswijk Dutch and standard Dutch. This shows that the dimensions of morpho(syntactic) diversity attested at the micro-comparative level need not be fundamentally different from those found at the meso-comparative level.

Acknowledgements We would like to thank the audience of the Comparative Germanic Syntax Workshop 22 in Stuttgart, the audience of the Wednesday Syntax Meeting in Leiden, and five anonymous reviewers of the Journal of Comparative Germanic Linguistics for their valuable comments. Furthermore, we are very grateful to the informants of the DiDDD-project for their time, patience and help with the dialectal data. Finally, we would like to thank The Netherlands Organisation for Scientific Research (NWO) for supporting this research financially. The authors are listed alphabetically.

Open Access This article is distributed under the terms of the Creative Commons Attribution Noncommercial License which permits any noncommercial use, distribution, and reproduction in any medium, provided the original author(s) and source are credited.

\section{References}

Abney, S. 1987. The English noun phrase in its sentential aspect. Doctoral dissertation, MIT.

Barbiers, S. 2005. Variation in the morphosyntax of ONE. The Journal of Comparative Germanic Linguistics 8: 159-183.

Bennis, H., N. Corver, and M. den Dikken. 1998. Predication in nominal phrases. The Journal of Comparative Germanic Linguistics 1: 85-117.

Bobaljik, J., and S. Wurmbrand. 2005. The domain of agreement. Natural Language and Linguistic Theory 23: 809-865.

Carstens, V. 2000. Concord in minimalist theory. Linguistic Inquiry 31: 319-355.

Chomsky, N. 1995. The minimalist program. Cambridge: MIT.

Chomsky, N. 2001. Derivation by phase. In Ken Hale: A life in language, ed. M. Kenstowicz, 1-52. Cambridge: MIT.

Corver, N. 1990. The Syntax of Left Branch Extractions. Doctoral dissertation, Tilburg University.

Corver, N. 2003. A note on micro-dimensions of possession in Dutch and related languages. In Germania et alia. A Linguistic Webschrift for Hans den Besten, eds. J. Koster \& H. van Riemsdijk (http://odur. let.rug.nl/ koster/DenBesten/contents).

Corver, N. 2008. Uniformity and diversity in the syntax of evaluative vocatives. Journal of Comparative Germanic Linguistics 11: 43-93.

Corver, N., and M. van Oostendorp. 2005. Low Saxon possessive pronominals. Syntax and phonology. Linguistics in the Netherlands 2005, 73-86, Amsterdam/Philadelphia: Benjamins.

Corver, N., M. van Koppen, H. Kranendonk, and M. Rigterink. 2007. The noun phrase: Diversity in Dutch DP design. Nordlyd 34(1): 73-85.

Déchaine, R.-M., and M. Wiltschko. 2002. Decomposing pronouns. Linguistic Inquiry 33: 409-442.

den Besten, H. 2007. Possessor commanding possessum. Handout of a talk at Utrecht University, UiLOTS, 02-05-2007. Utrecht, Netherlands.

den Dikken, M. 1998. Predicate inversion in DP. In Possessors, predicates and movement in the determiner phrase, ed. A. Alexiadou and C. Wilder, 177-214. Amsterdam: Benjamins.

den Dikken, M. 2006. Relators and linkers: The syntax of predication, predicate inversion, and copulas. Cambridge: MIT.

Deunk, G.H. 1977. Grammatica van het Winterswijks, deel 2. Groningen: Sasland.

Duinhoven, A.M. 1988. Middelnederlandse syntaxis—synchroon en diachroon; deel 1: de naamwoordgroep. Leiden: Martinus Nijhoff.

Emonds, J. 1985. A unified theory of syntactic categories. Dordrecht: Foris. 
Haegeman, L. 2003. The external possessor construction in West Flemish. In From NP to DP. Volume II: The expression of possession, ed. M. Coene, Y. d'Hulst, and L. Tasmowski, 221-256. Amsterdam: Benjamins.

Kester, E.-P. 1996. The nature of adjectival inflection. Dissertation, University of Utrecht.

Koopman, H. 2001. The locality of agreement and the structure of the DP in Masaai. Manuscript, University of California Los Angeles.

Lobeck, A. 1995. Ellipsis: functional heads, licensing and ellipsis. Oxford: Oxford University Press.

Longobardi, G. 1994. Reference and proper names: A theory of N-movement in syntax and logical form. Linguistic Inquiry 25: 609-665.

Panagiotidis, Phoevos. 2002. Pronouns, clitics and empty nouns. 'Pronominality' and licensing in syntax. Amsterdam: Benjamins.

Postal, P. 1966. On so-called pronouns in English. In Modern studies in English, ed. D. Reibel and S. Schane, 201-223. Englewood Cliffs: Prentice-Hall.

Rizzi, L. 1986. Null Objects in Italian and the Theory of pro. Linguistic Inquiry 17: 501-557.

Royen, G. 1948. Buigingsverschijnselen in het Nederlands. Deel II. N. V.. Amsterdam: Noord-Hollandsche uitgevers maatschappij.

Schoorlemmer, M. 1998. Possessors, articles and definiteness. In Possessors, predicates and movement in the determiner phrase, ed. A. Alexiadou and C. Wilder, 55-86. Amsterdam: Benjamins.

Sleeman, P. 1996. Licensing empty nouns in French. Doctoral dissertation, University of Amsterdam.

Szabolcsi, A. 1994. The noun phrase. In Syntax and Semantics: The syntactic structure of Hungarian 27: 179-274.

ter Laan, K. 1953. Proeve van een Groninger spraakkunst. Winschoten: Van der Veer.

van de Craats, I., N. Corver, and R. Van Hout. 2000. Conservation of grammatical knowledge: On the acquisition of possessive noun phrases by Turkish and Moroccan learners of Dutch. Linguistics 38: $221-314$

Vergnaud, J., and M.L. Zubizarreta. 1992. The definite determiner and the inalienable construction in French and English. Linguistic Inquiry 23: 595-652.

Wakelin, M. 1972. English dialects. An introduction. London: Athlone.

Wolfram, W., and N. Schilling-Estes. 1998. American English. Dialects and variation. Malden: Blackwell. 